\title{
The Intricate Interplay between Epigenetic Events, Alternative Splicing and Noncoding RNA Deregulation in Colorectal Cancer
}

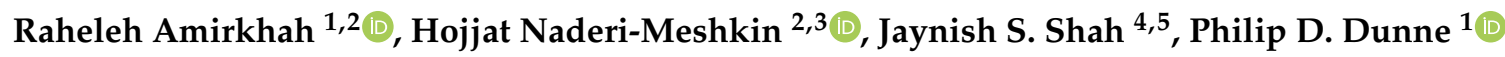 \\ and Ulf Schmitz $4,5,6, *$ (D) \\ Centre for Cancer Research and Cell Biology, Queen's University Belfast, Belfast BT9 7AE, UK \\ Nastaran Center for Cancer Prevention (NCCP), Mashhad 9185765476, Iran \\ 3 Stem Cells and Regenerative Medicine Research Group, Academic Center for Education, Culture \\ Research (ACECR), Khorasan Razavi Branch, Mashhad 9177949367, Iran \\ 4 Gene \& Stem Cell Therapy Program Centenary Institute, The University of Sydney, \\ Camperdown, NSW 2050, Australia \\ 5 Sydney Medical School, The University of Sydney, Camperdown, NSW 2050, Australia \\ 6 Computational BioMedicine Laboratory Centenary Institute, The University of Sydney, \\ Camperdown, NSW 2050, Australia \\ * Correspondence: u.schmitz@centenary.org.au
}

Received: 31 July 2019; Accepted: 16 August 2019; Published: 19 August 2019

check for updates

\begin{abstract}
Colorectal cancer (CRC) results from a transformation of colonic epithelial cells into adenocarcinoma cells due to genetic and epigenetic instabilities, alongside remodelling of the surrounding stromal tumour microenvironment. Epithelial-specific epigenetic variations escorting this process include chromatin remodelling, histone modifications and aberrant DNA methylation, which influence gene expression, alternative splicing and function of non-coding RNA. In this review, we first highlight epigenetic modulators, modifiers and mediators in CRC, then we elaborate on causes and consequences of epigenetic alterations in CRC pathogenesis alongside an appraisal of the complex feedback mechanisms realized through alternative splicing and non-coding RNA regulation. An emphasis in our review is put on how this intricate network of epigenetic and post-transcriptional gene regulation evolves during the initiation, progression and metastasis formation in CRC.
\end{abstract}

Keywords: chromatin remodelling; histone modifications; aberrant DNA methylation; long non-coding RNA; microRNA

\section{Introduction}

Besides genomic instability and mutations, the disruption of epigenomic control is a known characteristic of cancer cells [1,2]. It was shown that the development of CRC is driven by an accumulation of genetic and epigenetic aberrations [3].

CRC pathogenesis is associated with three major pathways, which are the basis for molecular subtyping of CRC: microsatellite instability (MSI), chromosomal instability (CIN), and the epigenomic CpG island methylator phenotype (CIMP) [4]. Additionally, an international Colorectal Cancer Subtyping Consortium introduced four consensus molecular subtypes (termed CMS1-4), which are largely based on transcription signalling associated with components of the tumour microenvironment including CMS1 (MSI immune), CMS2 (canonical), CMS3 (metabolic) and CMS4 (mesenchymal) [5]. Although this taxonomy provided a basis for research in the CRC field, increasing evidence has revealed that epigenetic alterations, including DNA methylation, histone marks, chromatin remodelling, and noncoding RNAs (ncRNAs) play pivotal roles in the development of CRC, supporting the idea that 
epigenetic signatures can be used to further stratify the spectrum of heterogenous CRC phenotypes into molecular subtypes associated with patient prognosis and treatment response.

In this review, we focus on epigenetics, alternative splicing, ncRNAs, and the interplay between these mechanisms of gene regulation in CRC initiation, progression and metastasis.

\section{Epigenetic Modulators, Modifiers and Mediators in CRC}

Epigenetic alterations are strongly associated with neoplastic transformation in CRC [6,7]. Epigenetically induced activation of proto-oncogenes and silencing of tumour-suppressors play a central role in the complexity of cancer emergence, progression and response to treatment $[7,8]$. Therefore, understanding epigenetic changes as a driving force in colorectal neoplasia opens up new opportunities for the identification of reliable epi-biomarkers and the development of targeted epigenetic therapies in CRCs.

Recently, Feinberg et al. introduced a cancer epigenetics framework in which genes act as epigenetic modulators, modifiers or mediators [9]. In their model, epigenetic modulators regulate the activity of modifiers that, in turn, induce the expression of epigenetic mediators (Figure 1). Mediators dynamically change through feedback loops that target epigenetic modifiers, thereby shaping the Waddington landscape of cancer development in which mediators bring about a cellular transition towards a cancer stem cell state favouring tumour progression [9]. A deregulated epigenome often caused by environmental factors and facilitated by the interplay between modulators, modifiers and mediators can result in the intra-tumoural cellular heterogeneity that enables tumour evolution $[9,10]$.

The same cascade of epigenetic modulators, modifiers and mediators can be documented in CRC. Epigenetic subtypes of CRC are strongly associated with specific somatic mutations that drive the step-wise progression of CRC [6,11-14]. During the early stages of CRC development, the normal colorectal epithelium is transformed into a benign adenoma by inactivation mutations in tumour suppressor genes (e.g., APC, TP53, SMAD4) and activating mutations in proto-oncogenes (KRAS, BRAF, PIK3CA) $[1,15,16]$. Subsequently, through the sequential alterations in epigenetic modifiers $[17,18]$ and mediators [19], adenoma progresses to carcinoma and subsequently advances to an invasive and metastatic tumour $[6,20]$. Therefore, epigenetic modulators, modifiers and mediators work together in generating phenotypic variations of cancerous cells (Figure 1).

Using CRISPR gene editing, Matano et al. created CRC organoids with loss of function mutations in APC, SMAD4 and TP53, and gain-of-function mutations in KRAS and/or PIK3CA that grew independent from niche factors in vitro, and formed tumours after implantation under the kidney sub-capsule in mice [21]. They suggested that driver pathway mutations in epigenetic modulators facilitate the preservation of stem cells in the tumour microenvironment. However, further molecular lesions would be necessary for invasive behaviour. Another study sequentially introduced both inactivation mutations in tumour suppressor genes (APC, TP53, and SMAD4) and an oncogenic mutation in the KRAS oncogene to create CRC organoids from intestinal stem cells [21]. By studying this CRISPR-mutated organoid containing four of the most frequently mutated CRC genes, they have demonstrated that quadruple mutants grow independent from niche factors as invasive carcinomas and combined loss of APC and P53 is sufficient for acquiring CIN [22]. Another group has genetically dissected CRC progression (adenoma-carcinoma sequence) by orthotopic transplantation of CRISPR-engineered CRC organoids to study the contribution of common CRC key mutations (in Wnt, EGFR, P53, and TGF- $\beta$ signalling pathways) to metastasis [23]. Lannagan et al. generated complex preclinical models of serrated CRC by serial introduction of inactivation mutations in five genes (MLH1, TGFBR2, RNF43, ZNRF3, and p16Ink4a) in BRAF ${ }^{\mathrm{V} 600 \mathrm{E}}$ organoids [24]. Although these studies have validated the critical role of mutations in epigenetic modulators in CRC development, emerging studies have shown that mutations in epigenetic modulators such as $\mathrm{BRAF}^{\mathrm{V} 600 \mathrm{E}}$ and $\mathrm{KRAS}^{\mathrm{G} 13 \mathrm{D}}$ are tightly connected with the $\mathrm{CpG}$ island methylator phenotype (CIMP), which is generated by epigenetic modifiers $[13,14,25,26]$. These studies support the epigenetic functional framework depicted in Figure 1. 


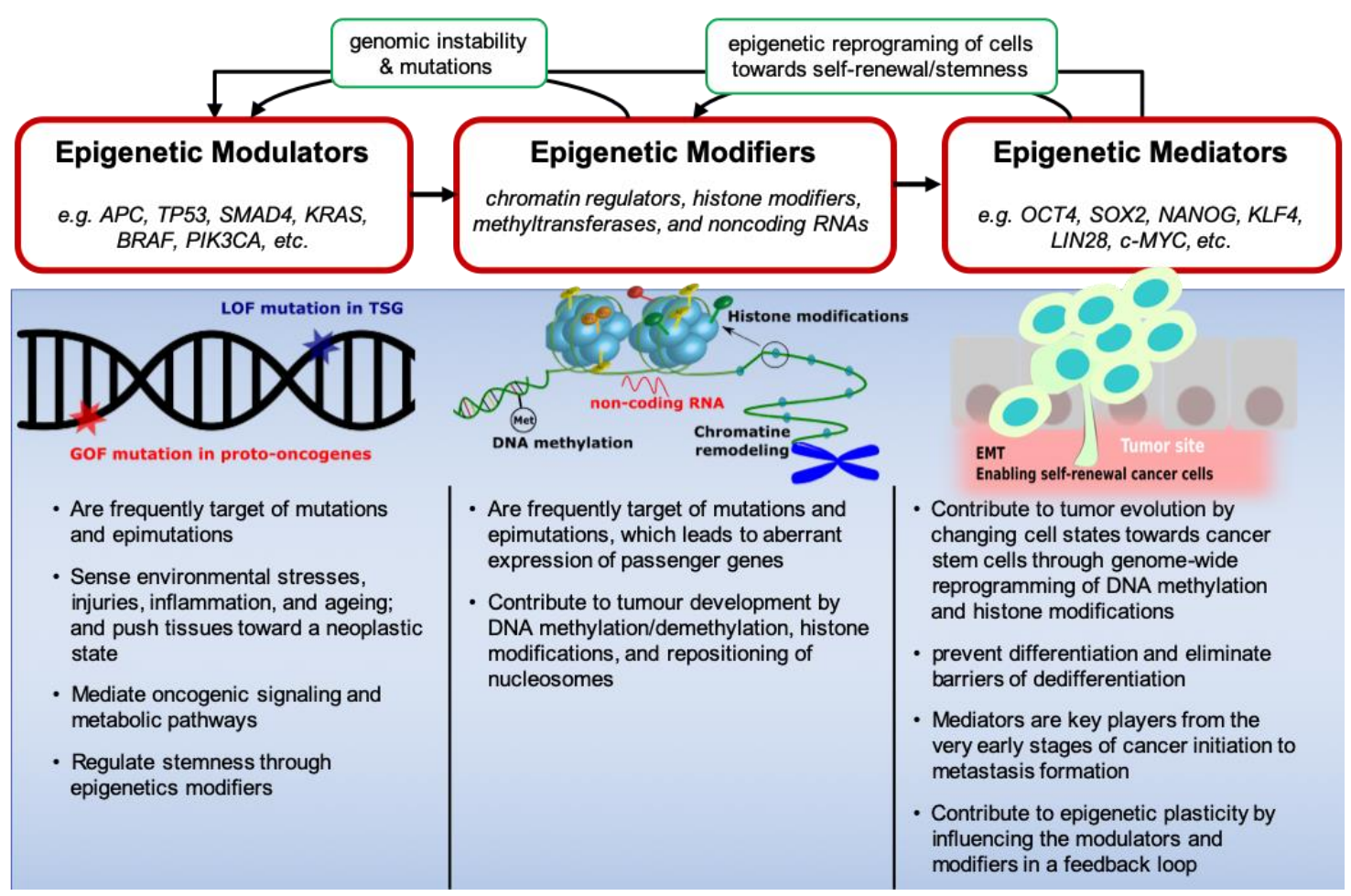

Figure 1. Epigenetic functional system in the initiation and progression of CRC. Environmental cues, such as repeated exposure to carcinogens, inflammation, injury, and ageing impinge on epigenetic modulators. These, in turn, destabilize the epigenome through signalling and metabolic pathways. As a result, chromatin states at epigenetic mediator genes are changed triggering their unscheduled expression. Epigenetic mediators can also influence the plasticity of tumour cells during neoplasia, giving rise to the formation of CSCs and metastases. In all these processes, epigenetic modifiers play a central role. Mutations are frequently seen in epigenome modifying genes and, conversely, the epigenetic changes can cause further mutations and genomic instability in modulators. LOF $=$ loss of function; TSG = tumour suppressor gene; GOF = gene of interest; Met = methylation; $\mathrm{EMT}$ = epithelial to mesenchymal transition.

Although the role of $B R A F$ and $K R A S$ mutations in the development of CRC is well documented, the chicken-or-egg problem for $C R C$ is to definitively prove whether mutations in epigenetic modulators eventually lead to CIMP or CIMP appears first and creates an environment that facilitates mutations in epigenetic modulators. Interestingly, evidence for both hypotheses has been found, suggesting that there are ultimately different pathways for epithelial cells to progress towards cancerous phenotypes in cancer development. The BRAF ${ }^{\mathrm{V} 600 \mathrm{E}}$ mutation has been shown to result in CIMP development via increased BRAF/MEK/ERK signalling, which causes MAFG upregulation and phosphorylation. The transcriptional repressor MAFG, in turn, recruits a corepressor complex that includes the chromatin remodelling factor CHD8 and the DNA methyltransferase DNMT3B to CpG islands in the promoters of CIMP genes [25]. In another study, acquisition of the KRAS ${ }^{\mathrm{G} 13 \mathrm{D}}$ mutation resulted in the upregulation of zinc-finger DNA-binding protein ZNF304. As a consequence, ZNF304 recruits DNA methyltransferase DNMT1 to CIMP gene promoters causing aberrant hypermethylation [27]. Conversely, other studies have shown that aberrant DNA hypermethylation and CIMP provides a permissive context for mutations in the BRAF gene $[13,14,26]$.

Epithelial to mesenchymal transition (EMT)-associated reprogramming of normal and tumour epithelial cells is a result of fundamental changes in several regulatory networks and the interplay between them [28]. Impaired epithelial balance can contribute to the acquisition of a cancerous state, e.g., through the deregulation of epigenetic control mechanisms, the transcriptional machinery, alternative splicing, the expression of non-coding RNAs or alterations in translation and protein 
stability [28]. Widschwendter et al. showed that cancers may have a stem cell origin in which reversible gene repression normally imposed by an epigenetic modifier (e.g., Polycomb group proteins) is replaced by constant silencing, locking cells into a permanent state of self-renewal that predisposes them to malignant transformation [11]. Another study demonstrated that driver mutations are significantly associated with aberrant DNA methylation in many cancer types, including CRC, and that these epigenetic changes contribute to carcinogenesis. These driver mutation-methylation patterns can be used to classify heterogeneous cancers into subtypes [12]. Recently, an integrative genome-wide DNA methylation and transcriptomic analysis of 216 CRC samples revealed five clinically and molecularly distinct subtypes of colorectal adenocarcinomas, along with an association between genomic methylation and age [26].

Besides genetic instability and mutations, epigenomic disruption can contribute to transformation and the development of cancer-associated phenotypes [1,2]. Understanding the network of epigenetic modifiers provides information to interpret the functional significance of epigenetic drivers of tumorigenesis [2,29]. Epigenetic modifications, as an instructive layer, act on the genome and can be cell type-specific [30,31]. Defects in epigenetic effectors (readers, writers and erasers) mediate the development of cancers, including CRC $[1,17,30,31]$. Thus, we next focus on epigenetic modifiers and their interactions in CRC cell regulation.

\section{The Interplay between Non-Coding RNAs and Epigenetics in CRC}

The interplay between epigenomics and non-coding RNA (ncRNA) expression and function is currently receiving a lot of attention. Elucidation of this intricate regulatory network between ncRNAs and epigenetic factors may offer new insights into the molecular mechanisms involved in the pathogenesis of CRC and promote accurate diagnostic and prognostic biomarkers, as well as facilitate the development of novel personalized therapeutic approaches. Especially, the ubiquitous functions of long ncRNAs (lncRNAs) in CRC and elsewhere have been subject of many recent reviews [32-36]. LncRNAs have been implicated in diverse biological functions, e.g., acting as a scaffold for interactions between various macromolecules, as a signal for the recruitment of the transcription machinery, as a guide for the localization of ribonucleoproteins or as a decoy for microRNAs (miRNAs) or proteins $[37,38]$. LncRNAs regulate gene expression at the epigenetic level (by regulating chromatin remodelling, DNA methylation, or histone modification), the transcriptional level (by association with transcription factors, enhancers or promoters), and post-transcriptional level (via alternative splicing, transport and translation of pre-mRNA, or by interacting with miRNAs).

LncRNAs are often dysregulated in the pathological processes of CRC, functioning as oncogenes or tumour-suppressors [3,34,35,39]. For example, lncRNA DLEU1 promotes CRC cell proliferation and migration by recruiting SMARCA1, a subunit of the NURF chromatin remodelling complex, to the promoter of KPNA3, a gene whose expression is associated with a lower survival rate and poorer prognosis in CRC patients [40].

\subsection{Noncoding RNAs and DNA Methylation in CRC}

DNA methylation, in combination with other epigenetic events, has been associated with different phenotypes of CRC including CIN, MSI and CIMP [41,42]. For example, a recent study has shown that global hypomethylation is significantly associated with CIN in sporadic CRC [43]. Another study confirmed the strong correlation between global DNA hypomethylation and CIN but also found that the MSI phenotype correlates with regional hypermethylation [44]. Interestingly, they found that CRC cells with CIN have an open chromatin conformation and are enriched in histone acetylation, both in repetitive elements and coding regions. Conversely, MSI phenotypes have a higher incidence of closed chromatin structures alongside low levels of histone acetylation. This supports the notion that patterns of DNA methylation in combination with other epigenetic changes have an impact on phenotype-specific gene expression and CRC pathogenesis [44]. 
Aberrant DNA methylation also contributes to later stages of CRC, for example by establishing a CIMP phenotype through global genome hypermethylation, which results in silencing of tumour suppressor genes, such as CDKN2A/p16 [45]. CIMP has a strong association with the occurrence of somatic mutations at driver oncogene loci, such as $\mathrm{BRAF}^{\mathrm{V} 600 \mathrm{E}}$ and $\mathrm{KRAS}{ }^{\mathrm{G} 13 \mathrm{D}}$; supporting the existence of links between genetic mutations and DNA methyltransferases [25,27]. The association of driver mutations, including $\mathrm{BRAF}^{\mathrm{V} 600 \mathrm{E}}$ and $\mathrm{KRAS}^{\mathrm{G} 13 \mathrm{D}}$ with methylation patterns can be used to stratify the heterogeneous cell population of a tumour into homogeneous subtypes [12].

Epigenomic and transcriptomic profiling of the colon cancer cell line DLD1 showed that a signature of mRNAs, miRNA, IncRNAs, and epigenetic alterations are associated with CRC metastasis. In particular, global hypomethylation of gene-regulatory regions was found during tumour progression, with the lowest degree of methylation present in metastases-isolated cells. Due to promoter demethylation, the expression of H19 was elevated, a lncRNA which is associated with poor survival [46]. Using a CRISPR loss-of-function screen, McCleland et al. identified a member of the bromodomain and extra terminal (BET) protein family (BRD4) as a key epigenetic regulator, which interacts with IncRNA CCAT1 for BET-mediated c-MYC regulation in CIMP+ CRC; suggesting CCAT1 as a predictor of sensitivity to BET inhibitor drug JQ1 [47]. Chromatin readers such as BET are considered druggable targets for cancer treatment [48].

LncRNAs can regulate genome-wide DNA methylation in association with the methyltransferase DNMT1, especially DACOR1 (DNMT1-associated Colon Cancer Repressed lncRNA 1), which has a highly tissue-specific expression in the normal colon [49]. The induction of tumour suppressor DACOR1 in colon cancer cells restores DNA methylation of thousands of CpG dinucleotides at hypomethylated sites in colon tumours including intergenic regions, promoters and gene bodies of oncogenic transcription factors such as FOS and JUN [50].

5-hydroxymethylcytosine $(5 \mathrm{hmC})$ is the first oxidative intermediate product of the 5 -methylcytosine $(5 \mathrm{mC})$ demethylation by the ten-eleven translocation (TET) protein family. Apart from its intermediate role in the cytosine demethylation pathway, $5 \mathrm{hmC}$ has multifaceted regulatory functions with emerging importance in cancer [51-55]. Hu et al. indicated that abnormal tumour-specific enhancers and/or promoters modified by $5 \mathrm{hmC}$ promote dysregulation of CRC-related lncRNAs such as TCONS_12_00000584 and LINC00189 [53]. Mechanistically, 5hmC, along with histone marks and transcription factors, determinate open chromatin structures to facilitate long-range chromatin interactions at lncRNA loci and thus regulate lncRNA transcription. LncRNA enhancers marked with $5 \mathrm{hmC}$ show higher transcriptional activity than enhancers without $5 \mathrm{hmC}$ mark, thereby contributing to the pathogenesis of CRC [53].

Another lncRNA named HIF1A-AS2 plays an oncogenic role by acting as a competing endogenous RNA. HIF1A-AS2 is a decoy for miR-129-5p, whereby it indirectly promotes DNA Methyltransferase 3 Alpha (DNMT3A) expression and positively affects EMT and progression of CRC [56]. Interestingly, miRNA expression is regulated by DNA methylation and histone modifications as well during CRC tumorigenesis. Almost $10 \%$ of all miRNAs are regulated by DNA methylation in CRC cells [57]. DNA methylation-mediated repression of three miRNAs (miR-181a, miR-135a and miR-302c) promotes CRCs with MSI and 5-FU resistance according to Shi et al. [58]. MiRNA-132 was proven to undergo transcriptional inactivation by DNA hypermethylation and implies a poor prognosis in CRC [59]. Another study has identified that miR-133b is markedly downregulated through promoter hypermethylation in human CRC tissues compared to healthy colon cells [60].

MiRNAs are also involved in DNA methylation regulation. Low miR-203 expression in CRC, for example, indirectly causes $A B C G 2$ promoter methylation lowering the expression of this important efflux transporter and thereby CRC development. MiR-203 targets DNA Methyltransferase 3 Beta (DNMT3B), which is relieved from post-transcriptional repression in CRC and can, therefore, methylate the $A B C G 2$ promoter [61].

An overview of the interplay between ncRNAs and DNA methylation in CRC is provided in Table 1. 
Table 1. Interplay of ncRNAs with DNA methylation in the pathogenesis of CRC.

\begin{tabular}{|c|c|c|c|c|}
\hline $\begin{array}{l}\text { Non-Coding } \\
\text { RNAs }\end{array}$ & $\begin{array}{l}\text { Epigenetic Partner/Other } \\
\text { Epigenetic Mediator }\end{array}$ & Target Gene & Tumorigenic Effects & Reference \\
\hline \multicolumn{5}{|c|}{ LncRNA \& DNA methylation } \\
\hline DACOR1 & $\begin{array}{l}\text { interaction with DNMT1 to } \\
\text { reprogram genome-wide DNA } \\
\text { methylation }\end{array}$ & $\begin{array}{l}\text { DNA methylation } \\
\text { at thousands of } \\
\text { CpG sites }\end{array}$ & increased clonogenicity & {$[49,50]$} \\
\hline HIF1A-AS2 & $\begin{array}{l}\text { regulates miR-129-5p and } \\
\text { DNMT3A expression }\end{array}$ & & $\begin{array}{l}\text { progression and EMT } \\
\text { formation of CRC }\end{array}$ & [56] \\
\hline H19 & $\begin{array}{l}\text { hypomethylation of the sixth } \\
\text { CTCF-binding site in the } \\
\text { differentially methylated } \\
\text { region of IGF2/H19 }\end{array}$ & $\begin{array}{l}\text { loss of imprinting } \\
\text { of } I G F 2 T \rightarrow \text { two } \\
\text { forms of aberrant } \\
\text { IGF2 expression }\end{array}$ & $\begin{array}{l}\text { promotes microsatellite } \\
\text { instability and oncogenesis }\end{array}$ & [62-64] \\
\hline \multicolumn{5}{|c|}{ MicroRNA \& DNA methylation } \\
\hline $\operatorname{miR}-133 b$ & promoter hypermethylation & $\begin{array}{l}\text { HOXA9/ZEB1 } \\
\text { pathway }\end{array}$ & $\begin{array}{c}\text { inhibits migration and } \\
\text { apoptosis; suppresses } \\
\text { metastasis }\end{array}$ & {$[60,65]$} \\
\hline miR-149 & $\begin{array}{l}\text { epigenetically silenced by } \\
\text { DNA methylation }\end{array}$ & $\begin{array}{l}\text { Specificity Protein } 1 \\
\text { (SP1) }\end{array}$ & $\begin{array}{l}\text { independent prognostic } \\
\text { factor for overall survival }\end{array}$ & [66] \\
\hline miR-132 & $\begin{array}{c}\text { downregulation by DNA } \\
\text { hypermethylation }\end{array}$ & paxillin & $\begin{array}{l}\text { associated with cell } \\
\text { invasion }\end{array}$ & [59] \\
\hline miR-345 & $\begin{array}{l}\text { CpG island promoter } \\
\text { hypermethylation }\end{array}$ & $\begin{array}{l}\text { BCL2-associated } \\
\text { athanogene } 3 \\
\text { (BAG3) }\end{array}$ & $\begin{array}{l}\text { suppresses colon cancer } \\
\text { cell proliferation and } \\
\text { invasiveness }\end{array}$ & [67] \\
\hline miR-181a/135a/302c & $\begin{array}{l}\text { DNA methylation-mediated } \\
\text { repression }\end{array}$ & $\begin{array}{l}\text { via repressing } \\
\text { PLAG1/IGF2 } \\
\text { signalling }\end{array}$ & $\begin{array}{l}\text { promotes the } \\
\text { microsatellite-unstable } \\
\text { CRC development and } \\
\text { 5-FU resistance }\end{array}$ & [58] \\
\hline $\operatorname{miR}-203$ & directly targets DNMT3B & $\begin{array}{l}\text { causes } A B C G 2 \\
\text { promoter } \\
\text { methylation }\end{array}$ & $\begin{array}{c}\text { predisposing CRC } \\
\text { development by lowering } \\
\text { expression of ABCG2. }\end{array}$ & [61] \\
\hline
\end{tabular}

\subsection{Noncoding RNAs, Chromatin Remodeling, and Histone Modifications in CRC}

Among many other functions, IncRNAs are involved in the cis- and trans-regulation of gene expression. For example, the non-coding RNA DLEU1 contributes to CRC development and progression by recruiting SMARCA1, an essential subunit of the NURF chromatin remodelling complex, to the promoter of the KPNA3 gene. High expression of DLEU1 and KPNA3 correlated with poor prognosis in CRC patients [40].

Several studies have shown that three lncRNAs (CCAT1-1, CCAT1 and CCAT2), located upstream of the proto-oncogene $M Y C$, are highly expressed in microsatellite-stable CRC and have been implicated in CRC predisposition by different mechanisms of action [68-71]. Xiang et al. have shown that CCAT1-L promotes CRC-specific chromatin looping through long-range interactions between the MYC promoter and its upstream enhancers. Additionally, CCAT1-L modulates chromatin conformation at these loop regions by interacting with CTCF [70]. It was shown that upregulation of c-MYC facilitated by a large chromatin loop is linked to a cancer risk-associated single-nucleotide polymorphism (SNP, rs6983267) in CRC cells. Later, Ling et al. demonstrated that the same SNP affects CCAT2 expression and the risk allele of SNP rs6983267 produces more lncRNA CCAT2 transcript, which in turn up-regulates MYC, miR-17-5p, and miR-20a through physical interaction with transcription factor TCF7L2. This results in an enhancement of WNT signalling activity. CCAT2 itself is a downstream target of WNT, suggesting the existence of a feedback loop [68]. Recent studies confirmed that CCAT1 and CCAT2 promote chromosomal instability in CRC pathogenesis and metastasis progression. Both lncRNAs are considered valuable prognostic markers for CRC since high expression of CCAT1 and CCAT2 are associated with cancer recurrence and poor overall survival $[69,71]$. 
Epigenetic interplay with lncRNAs also affects advanced stages of CRC. Kogo et al., for example, revealed that the IncRNA HOTAIR, in cooperation with the PRC2 complex widely reprograms chromatin organization and thereby promotes liver metastases in stage IV CRC patients [72].

Besides DNA methylation and chromatin remodelling, histone modifications are also recognized as early epigenetic events in cancers including CRC. Histone modifications recognized as the histone code' affect chromatin structure and gene expression during tumorigenesis. In an integrated analysis of RNA sequencing data of matched primary tumours, synchronous liver metastases and normal colon tissues, as well as H3K4me3 ChIP-seq data, Chen et al. observed that H3K4me3 was enriched at transcription start sites of IncRNAs dysregulated in CRC [73].

$\mathrm{Xu}$ et al. demonstrated that lncRNA SNHG1 directly interacts with the EZH2 subunit of Polycomb Repressive Complex 2 (PRC2) and modulates histone methylation of Kruppel like factor 2 (KLF2) and CDKN2B promoters in CRC [74]. SNHG1 also functions as a miRNA sponge in the cytoplasm and increases Cyclin D2 (CCND2) expression by sequestering miR-154-5p [74]. We collated other examples of IncRNAs that sponge miRNAs in CRC in Supplementary Table S1. Ding et al. revealed that lncRNA CRNDE (Colorectal Neoplasia Differentially Expressed) epigenetically silences DUSP5 and CDKN1A expression by binding to EZH2, a key component of the PRC2 complex. Thereby, CRNDE contributes to advanced pathological stages in CRC [75].

DNA methylation and histone modifications appear to mutually reinforce silencing of tumour-suppressor genes in CRCs. Wang et al., for example, have found that long non-coding RNA 34 (or Lnc34a) recruits DNMT3A via Prohibitin-2 (PHB2) and Histone Deacetylase 1 (HDAC1) to simultaneously methylate and deacetylate the MIR34A promoter [76]. Thereby, miR-34a transcription is epigenetically switched off. Interestingly, microscopy experiments showed that Lnc34a is distributed unevenly when colon cancer cells divide so that the production of miR-34a is asymmetrically inhibited in one daughter cell but not the other. Wang et al. confirmed that Lnc34a is upregulated in late-stage CRCs and overexpressed in cancer stem cells, which helps them to proliferate more rapidly [77].

LncRNA themselves are regulated by histone modifications. The transcription factor Ets-1 negatively regulates BRAF-activated lncRNA (BANCR) expression by binding and deacetylating histone $\mathrm{H} 3$ within the $B A N C R$ promoter during CRC progression [78].

An overview of the interplay between lncRNAs and epigenetic events in CRC is provided in Table 2.

Table 2. Interplay of lncRNAs with other epigenetic partners in the pathogenesis of CRC.

\begin{tabular}{|c|c|c|c|c|}
\hline $\begin{array}{l}\text { Non-Coding } \\
\text { RNAs }\end{array}$ & $\begin{array}{l}\text { Epigenetic Partner/Other } \\
\text { Epigenetic Mediator }\end{array}$ & Target Gene & Tumorigenic Effects & Reference \\
\hline \multicolumn{5}{|c|}{ Chromatin remodelling } \\
\hline DLEU1 & $\begin{array}{l}\text { recruits SMARCA1, an } \\
\text { essential subunit of the NURF } \\
\text { chromatin remodelling } \\
\text { complex }\end{array}$ & $\begin{array}{l}\text { activation of } \\
\text { KPNA3 }\end{array}$ & $\begin{array}{l}\text { CRC development and } \\
\text { progression }\end{array}$ & [40] \\
\hline CCAT1-L & $\begin{array}{l}\text { regulates long-range } \\
\text { chromatin interactions }\end{array}$ & $\begin{array}{l}\text { activates the } \\
\text { transcription of the } \\
\text { MYC locus }\end{array}$ & $\begin{array}{l}\text { both tumorigenesis and the } \\
\text { metastatic process }\end{array}$ & [79] \\
\hline HOTAIR & $\begin{array}{l}\text { reprograms chromatin } \\
\text { organization in cooperation } \\
\text { with the PRC2 complex }\end{array}$ & $\begin{array}{l}\text { global epigenetic } \\
\text { regulation }\end{array}$ & $\begin{array}{c}\text { contributes to liver } \\
\text { metastases in stage IV CRC } \\
\text { patients }\end{array}$ & [79] \\
\hline \multicolumn{5}{|c|}{ Histone modification } \\
\hline MALAT1 & $\mathrm{EZH} 2$ & $\begin{array}{l}\text { represses } \\
\text { E-cadherin }\end{array}$ & promotes chemoresistance & [80] \\
\hline HULC & interacts with EZH2 & to repress $N K D 2$ & oncogenic & [81] \\
\hline SNHG1 & $\begin{array}{l}\text { interacts with PRC2 in the } \\
\text { nucleus and acts as a } \\
\text { miR-154-5p sponge in the } \\
\text { cytoplasm }\end{array}$ & $\begin{array}{l}\text { modulates histone } \\
\text { methylation of } \\
\text { KLF2 and CDKN2B }\end{array}$ & tumour progression & [74] \\
\hline
\end{tabular}


Table 2. Cont.

\begin{tabular}{|c|c|c|c|c|}
\hline $\begin{array}{l}\text { Non-Coding } \\
\text { RNAs }\end{array}$ & $\begin{array}{l}\text { Epigenetic Partner/Other } \\
\text { Epigenetic Mediator }\end{array}$ & Target Gene & Tumorigenic Effects & Reference \\
\hline CRNDE & binds to EZH2 & DUSP5/CDKN1A & $\begin{array}{l}\text { positively correlates with } \\
\text { advanced pathological } \\
\text { stages and larger tumour } \\
\text { sizes }\end{array}$ & [75] \\
\hline SNHG17 & binds to the EZH2 & $p 57$ & promotes cell proliferation & [82] \\
\hline SH3PXD2A-AS1 & interacts with $\mathrm{EZH} 2$ & p57 and $K L F 2$ & $\begin{array}{l}\text { promotes cells proliferation, } \\
\text { migration and invasion }\end{array}$ & [83] \\
\hline SNHG6 & $\begin{array}{l}\text { recruits EZH2 to the p21 } \\
\text { promoter }\end{array}$ & $p 21$ & $\begin{array}{l}\text { positively correlates with } \\
\text { advanced tumour stage }\end{array}$ & [84] \\
\hline MEG3 & $\begin{array}{l}\text { interacts with PRC2 and } \\
\text { JARID2 to direct them to } \\
\text { target promoters }\end{array}$ & $\begin{array}{l}\text { Clusterin signalling } \\
\text { pathway }\end{array}$ & $\begin{array}{l}\text { inhibits cells proliferation } \\
\text { and migration }\end{array}$ & [85] \\
\hline PINT & $\begin{array}{l}\text { interacts with PRC2 to silence } \\
\text { genes }\end{array}$ & $\begin{array}{l}\text { p53 autoregulatory } \\
\text { negative } \\
\text { mechanism }\end{array}$ & $\begin{array}{l}\text { inhibits proliferation of } \\
\text { tumour cells }\end{array}$ & [86] \\
\hline PINT & interacts with PRC2 & EGR1 & inhibits tumour cell invasion & [87] \\
\hline PCAT6 & forms a complex with EZH2 & $\begin{array}{c}\text { activates } \\
\text { anti-apoptotic ARC }\end{array}$ & $\begin{array}{l}\text { inhibits colon cancer cell } \\
\text { apoptosis }\end{array}$ & [88] \\
\hline \multicolumn{5}{|c|}{ Histone modification/DNA methylation } \\
\hline Lnc34a & $\begin{array}{c}\text { recruits DNMT3A via PHB2 } \\
\text { and HDAC1 to methylate and } \\
\text { deacetylate the MIR34A } \\
\text { promoter simultaneously }\end{array}$ & $\begin{array}{l}\text { epigenetically } \\
\text { silence miR-34a }\end{array}$ & $\begin{array}{l}\text { Increase colon cancer stem } \\
\text { cells (CSCs) proliferation in } \\
\text { late-stage CRC s. }\end{array}$ & [77] \\
\hline HOXA11-AS & $\begin{array}{l}\text { scaffold for the chromatin } \\
\text { modification factors PRC2, } \\
\text { LSD1, and DNMT1 }\end{array}$ & & lymph node metastasis & {$[89,90]$} \\
\hline
\end{tabular}

\section{Regulation of Alternative Splicing in CRC}

Many recent studies have shown that alternative splicing (AS) is a key feature for transcriptomic variations in CRC [91-96]. AS increases the diversity of both non-coding RNAs (regulatory) and coding RNAs (protein isoforms). These transcriptome variations can be a result of either mutations in or aberrant expression of trans-acting splicing factors such as hnRNPL [97], SRSF1 (alias ASF/SF2) [98-100], and SRSF6 [101] or mutations in cis-regulatory sequences [102-104].

Several recent studies have demonstrated that RNA binding motif 4 (RBM4) initiates a hierarchical AS cascade in CRC development; implying that splicing is highly regulated in this process [105-107]. Lin et al. demonstrated that RBM4 and PTBP1 exhibit opposite effects on modulating the utilization of splicing factor SRSF3 exon 4. SRSF3, in turn, modulates the metastatic signature of CRC cells, by reprogramming the splicing variants of MAP4K4 with distinct effects on JNK phosphorylation and subsequent downstream signalling pathways [107]. Another study highlighted the potential value of targeting this splicing cascade for CRC treatment and demonstrated how cell migration and angiogenesis are increased via RBM4-regulated isoform expression of Nova1 (exon 4 skipping), SRSF6 (intron 2 retention), and VEGF165 upregulation. RBM4-mediated splicing regulation was shown to promote CRC progression [106].

\subsection{Epigenetic Regulators of Alternative Splicing in CRC}

Epigenetic splicing regulation works through different modes including (1) the modulation of the RNA Pol II elongation rate inducing either exon skipping or inclusion, (2) splicing factor recruitment or sequestration and (3) adaptor/scaffolding function. Modes of epigenetic regulation can lead to changes in splicing factor concentration both spatially and temporally. 


\subsubsection{Modulation of RNA Pol II Elongation Rate}

Several studies have shown that histone marks decorate specific exons to regulate RNA Pol II elongation and thus influence co-transcriptional splicing [108-110]. For example, Poly (ADP) ribose polymerase (PARP1) marks histones and thereby changes nucleosome deposition at specific exon-intron boundaries, which in turn affects RNA Pol II movement and finally alters AS decisions in a context-specific manner [110]. Riffo-Campos et al. showed that low nucleosome occupancy, due to differential histone marks at exon $4 \mathrm{~A}$ of KRAS, resulted in an accelerated RNA Pol II elongation rate and subsequent lower abundance of isoform 4A in the CRC cell lines HCT116 and SW48 [109]. Yuan et al. demonstrated in a CRC mouse model that mutation of the histone methyltransferase SETD2 slows down transcription elongation and thereby facilitates the removal of intron 2 of dishevelled segment polarity protein 2 (DVL2) pre-mRNA; thereby augmenting Wnt/ $\beta$-catenin signalling and tumorigenesis. Conversely, in normal cells SETD2-catalyzed H3K36me3, thus mediating intron 2 retention in the DVL2 transcript, which induces a premature stop codon. As a consequence, the DVL2 mRNA is degraded via nonsense-mediated decay [111]. Nonsense-mediated decay is a common mechanism of AS-coupled auto-regulation of diverse mRNAs triggered by the retention of an intron harbouring a premature stop codon [106,112].

\subsubsection{Splicing Factor Recruitment or Sequestration}

Chromatin structures and DNA methylation are important for splice site recognition [113-116]. Epigenetic events can also help to recruit splicing factors to a specific locus [117,118]. Using ChIP-seq and RNA-seq analyses Kfir et al. revealed that SF3B1, an essential component of the U2 snRNP complex, specifically binds nucleosomes positioned at short exons flanked by long intronic sequences, suggesting that differences in chromatin organization between exons and introns pinpoint splicing factors to their pre-mRNA targets and determine splicing decisions [119]. Kim et al. confirmed that splicing factors specifically bind to post-translationally modified histone residues near exons that are targets of AS [118].

Histone modifications, DNA methylation and epigenetic modifiers can team up to affect AS. Maunakea et al. revealed that alternatively spliced exons are enriched in DNA methylation and that DNA methylation in the gene body can enhance exon recognition by recruitment of the methyl-CpG binding protein 2 (MeCP2) [120]. Similarly, using reduced representation bisulfite sequencing (RRBS) data from primary colon tumours [121], Gelfman et al. confirmed that $5 \mathrm{mC}$ signals at CpG sites are accompanied with elevated nucleosome occupancy involved in exon recognition [122]. MeCP2, attracted through DNA methylation, is a writer of histone marks. Other chromatin-binding proteins such as heterochromatin protein 1 (HP1) read these histone marks and act as an adaptor for coupling transcription and AS of nascent pre-mRNA [123]. HP1 not only links histone methylation marks to RNA splicing but also contributes to the progression of CRC by affecting cell cycle-related genes, including CDK6 and $p 21[124,125]$. Davie et al. confirmed that some epigenetic marks such as histone $\mathrm{H} 3 \mathrm{~K} 4$ trimethylation in coordination with epigenetic writers and readers dynamically affect pre-mRNA splicing and vice versa [126].

Several studies have shown that active cellular mechanisms and mutations can dynamically change histone marks and preferential association of splicing factors with exons [126-128]. For example, the G13D mutation in KRAS impacts on the epigenetic modification of heterogeneous nuclear ribonucleoproteins (hnRNPs) that is involved in pre-mRNA splicing [129]. Riffo-Campos et al. suggest that KRAS mutations affect AS of EPDR1 and ZNF518B in CRC cells leading to differential isoform expression in these genes [130].

\subsection{Non-Coding RNAs and the Regulation of Alternative Splicing in CRC}

MiRNAs regulate gene expression post-transcriptionally by binding to partially complementary sites in the $3^{\prime}$ untranslated region of their target mRNAs and thereby mediating target degradation 
or translation repression [131]. The oncogenic miRNAs miR-1298 and miR-92a downregulate the expression of SFQ and RBM4 in CRC [132,133]. Reduced expression of RBM4 leads to increased levels of $\mathrm{nPTB}$ and specific exon 10 inclusion. $\mathrm{nPTB}$, in turn, increases FGFR2 IIIc (mesenchymal-specific isoform) and pyruvate kinase M2 (PKM2) transcripts, which result in the progression and metabolic signature of CRC cells [133]. Studies have shown that non-coding RNAs, histone modifications and splicing factors work together to realize the isoform switch of FGFR2 protein from the epithelia-type FGFR2 IIIb to the mesenchymal-type FGFR2 IIIc [133-135]. Isoform switching from PKM1 to PKM2 governed by PTBP1 and PTBP1-associated miR-1 and miR-133b is critical for the maintenance of the Warburg effect in CRC cells [136].

The involvement of lncRNAs in the regulation of AS is known and has been reviewed elsewhere [137-139]. AS is a highly tissue/cell type-specific process critical to generate protein isoforms. LncRNAs have an important role in the establishment and maintenance of cell type-specific splicing outcomes by interacting with several Polycomb-group proteins, histone modifiers and the chromatin-splicing adaptor complex, as well as splicing factors $[134,140]$. Thereby, lncRNAs can also contribute to CRC development [141,142]. For example, LINC01133 titrates the splicing factor SRSF6 away from its RNA targets and thereby inhibits epithelial-mesenchymal transition in CRC mouse models [141]. However, the exact underlying mechanism by which SRSF6 controls epithelial-mesenchymal transition and metastasis is yet to be defined. MALAT1 regulates AS by influencing the localization of SR splicing factors into nuclear speckle domains [140]. It thereby regulates cell-type-specific AS in a concentration- and phosphorylation-dependent manner [140,142]. Another study found that MALAT1 promotes tumour growth and metastasis in CRC by competitively binding to SFPQ (also known as Polypyrimidine Tract-Binding Protein-associated splicing factor) and releasing oncogene PTBP2 (polypyrimidine tract binding protein 2) from the SFPQ/PTBP2 complex [143]. Interestingly, MALAT1 and PTBP2 are overexpressed in CRC, but SFPQ remains unchanged in CRC tissues compared to adjacent normal tissues [143]. Another IncRNA named GAPLINC (Gastric adenocarcinoma predictive long intergenic noncoding RNA) can also bind to SFPQ, as well as NONO. SFPQ and NONO promote cell invasion, motility and metastasis in CRC, partly by inducing the expression of snail family zinc finger 2 (SNAI2) [144]. However, the exact underlying mechanisms remain to be elucidated.

Some lncRNAs are encoded on the antisense strand of the gene, whose isoform expression they influence via AS $[145,146]$. For example, UXT-AS1 promotes CRC progression by changing the expressed isoform of UXT from UXT1 to UXT2 via AS. UXT-AS1 is significantly upregulated in CRC and associated with poor prognosis [146].

We have summarized non-coding RNAs that have an impact on AS in CRC in Table 3. 
Table 3. List of noncoding RNAs regulating alternative splicing in CRC.

\begin{tabular}{|c|c|c|c|c|}
\hline $\begin{array}{l}\text { Non-Coding } \\
\text { RNAs }\end{array}$ & Mechanism of Action in AS & Target Gene & $\begin{array}{c}\text { Tumorigenic } \\
\text { Effect }\end{array}$ & Reference \\
\hline LINC01133 & $\begin{array}{c}\text { titrates SRSF6 away from its } \\
\text { targets }\end{array}$ & & $\begin{array}{l}\text { inhibits EMT and } \\
\text { metastasis }\end{array}$ & [141] \\
\hline GAPLINC & binds to PSF and NONO & SNAI2 & $\begin{array}{l}\text { promotes invasion } \\
\text { in CRC }\end{array}$ & [144] \\
\hline MALAT1 & $\begin{array}{l}\text { regulates SR splicing factor } \\
\text { distribution in nuclear } \\
\text { speckle domains }\end{array}$ & & NA & [140] \\
\hline MALAT1 & $\begin{array}{l}\text { binds to SFPQ and releases } \\
\text { oncogene PTBP2 from the } \\
\text { SFPQ/PTBP2 complex }\end{array}$ & & $\begin{array}{l}\text { promotes tumour } \\
\text { growth and } \\
\text { metastasis in CRC }\end{array}$ & [143] \\
\hline UXT-AS1 & $\begin{array}{l}\text { isoform switching from } \\
\text { UXT1 to UXT2 }\end{array}$ & UXT1 & $\begin{array}{l}\text { promotes cell } \\
\text { proliferation }\end{array}$ & [146] \\
\hline $\operatorname{miR}-1296$ & represses SFPQ expression & SFPQ & $\begin{array}{c}\text { accelerates CRC } \\
\text { progression }\end{array}$ & [132] \\
\hline $\operatorname{miR}-92 a$ & $\begin{array}{c}\text { causing imbalanced } \\
\text { expression of PTBP2 } \\
\text { through AS-coupled } \\
\text { nonsense mediated decay }\end{array}$ & RBM4 & $\begin{array}{l}\text { contributes to } \\
\text { progression and } \\
\text { metabolic signature } \\
\text { of CRC cells }\end{array}$ & [133] \\
\hline
\end{tabular}

In Figure 2 we summarized current knowledge about the intricate interplay of gene-regulatory mechanisms in CRC across multiple layers.

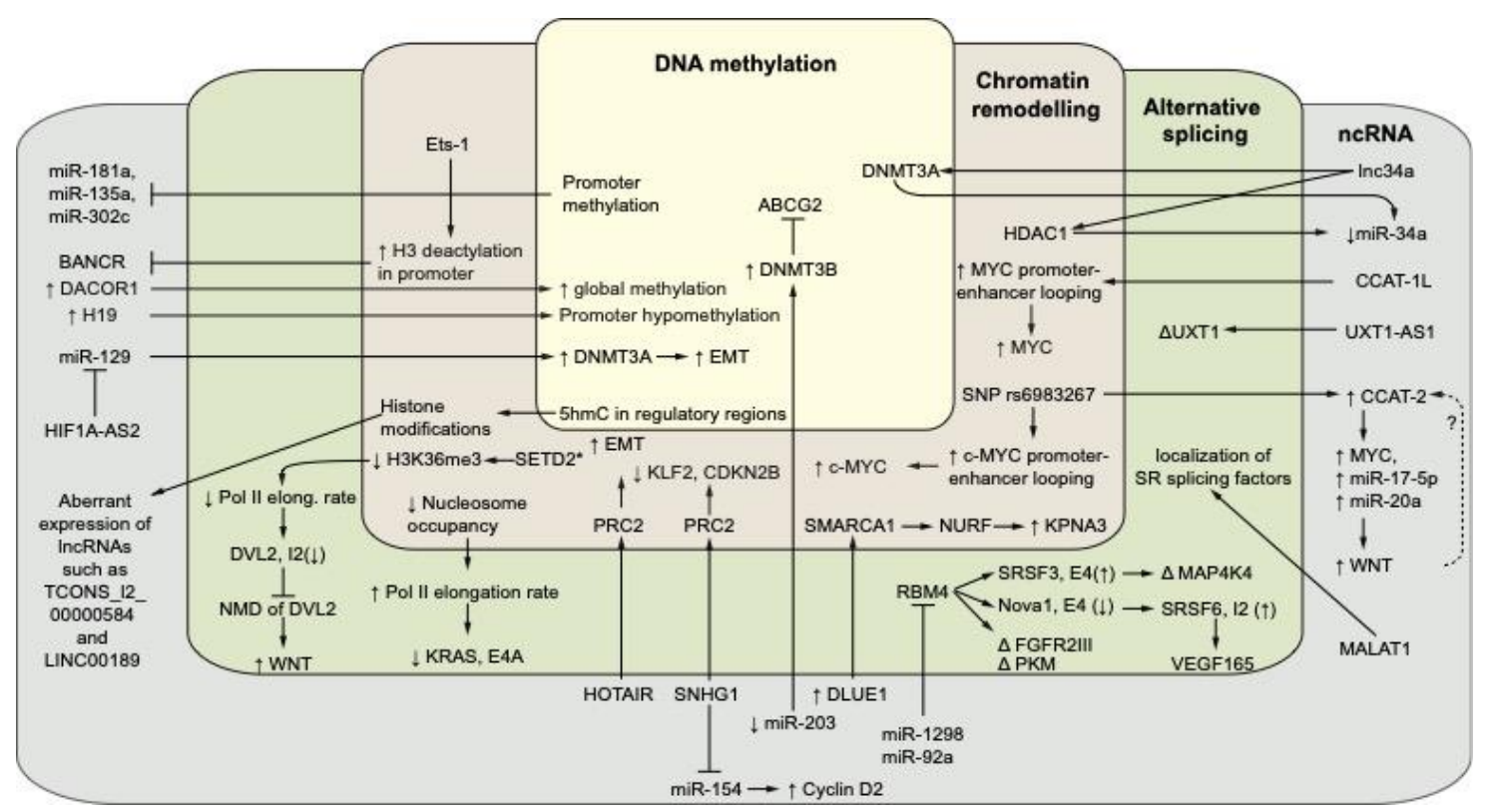

Figure 2. Overview of cross-talk between gene-regulatory layers in CRC. This figure depicts selected examples of the deregulated interplay between epigenetic events, alternative splicing (AS) and noncoding RNA in colorectal cancer. See the text of the manuscript for further details. $\uparrow$ and $\downarrow$ arrows represent up- or down-regulation or higher or lower activity of a factor, respectively. Intron and exons are abbreviated as E or I, respectively. In the cases of AS, $\uparrow$ and $\downarrow$ represent increased and decreased usage of an exon or intron, respectively. $\Delta$ represents isoform switching of a transcript due to AS. SET2D* represents a mutant of SET2D. The dashed arrow with question mark (?) represents a predicted feedback loop between WNT and CCAT-2. A vector graphics version of this figure is provided as Supplementary Figure S1. 


\section{Epi-Biomarkers and Promising Targets for the Design of epi-Drugs}

Understanding epigenetic regulation of gene and/or protein expression and integration of these factors with genomic data in the context of CRC genesis can help to develop novel epigenetic biomarkers for diagnosis and epigenetic drugs for the treatment of CRC patients. For example, the SEPT9 gene methylation assay, which aims to detect abnormal methylation at the SEPT9 promoter region, is the first FDA-approved assay for CRC screening using an epigenetic biomarker [147].

In addition to expression profiling of epigenetic modifiers (e.g., non-coding RNA), the assessment of the epigenetic state (e.g., DNA methylation) of epigenetic modulators and mediator genes can be utilized as prognostic, diagnostic and predictive biomarkers for CRC. Epigenetic modifiers have been shown to act in a cell type-specific manner and some were found highly stable in biofluids. This makes them attractive biomarkers. The biological significance of epigenetic modifiers has already been proven in CRC, and so has their potential to be used as epi-biomarkers for different CRC stages, including the early disease [148,149], EMT [56], metastasis [46], as well as the resistance to drugs [80,150]. Increased levels of lncRNAs such as HOTAIR, DLEU1 and UXT-AS1, which can alter the epigenetic landscape of CRC-promoting genes, have been shown to be associated with poor prognosis in CRC [40,72]. In addition to genome-wide DNA hypermethylation (CIMP phenotype), resulting in reduced expression of tumour suppressor genes, studies have revealed that transcriptional profiling of ncRNAs may offer further molecular stratification and subtyping of CRC patients [151,152]; supporting the idea that epigenetic modifiers should be considered in subtyping strategies.

Besides their potential as tractable biomarkers in CRC, epigenetic modifiers hold great promise for developing epi-drugs (Figure 3). In contrast to irreversible genetic mutations, epigenetic modifications are reversible and dynamic, thereby making them a promising therapeutic target [153]. Several FDA-approved examples of epi-drugs, such as HDACi and DNMTi, have already been tested in clinical settings [154]. A growing number of studies also support the use of ncRNAs as potential targets for anticancer drugs $[155,156]$. The first synthetic miRNA mimic to enter a clinical trial was MRX34 (NCT01829971), a miR-34a replacement. The aim of the trial was to evaluate the safety of MRX34 in patients with advanced solid tumours including CRC [157]. Although MIRX34 showed antitumour activity in a subset of patients, the project was terminated because of immune-related serious adverse events reported in five patients treated with MIRX34.

It has been demonstrated that some DNMT/HMT inhibitors and HDAC inhibitors exert their therapeutic effects by modulating the expression of regulatory non-coding RNAs including miRNAs [158] and lncRNAs [53]; implying that the effects between epigenetics modifiers are reciprocal. Even some lncRNAs such as HOTAIR mediate the reciprocal regulation between a histone-lysine N-methyltransferase enzyme (EZH2) and a DNA methyltransferase (DNMT1) [159]. Therefore, certain small molecule compounds such as AC1Q3QWB (AQB) are used in cancer therapy for selectively blocking HOTAIR-EZH2 interaction. The combinatorial use of AQB and 3-Deazaneplanocin A (DZNep; inhibitor of EZH2) offers an even more efficient treatment [160]. Another study has reported the use of an antisense oligonucleotide (ASO) to displace lncRNA XIST, the initiator of X-chromosome inactivation, from inactive X [161]. More ASOs targeting lncRNAs are currently in development [162].

Among the growing number of lncRNAs known to be involved in CRC, it is likely that more links between lncRNAs and epigenetic events will be found (see examples in Tables 1 and 2), such that combination therapies may provide a more effective treatment option. Such an approach could be achieved using ASOs against a CRC-specific lncRNAs or synthetically-engineered lncRNAs, in combination with current standard-of-care chemotherapies to ensure synergistic effects of epi-drugs.

Of note, many ncRNAs originate from cells in the tumour microenvironment (i.e., fibroblasts, immune cells, endothelial cells) and shuttle to cancer cells via exosomes, providing another option of therapy which has been extensively reviewed in our recently published article [163]. 


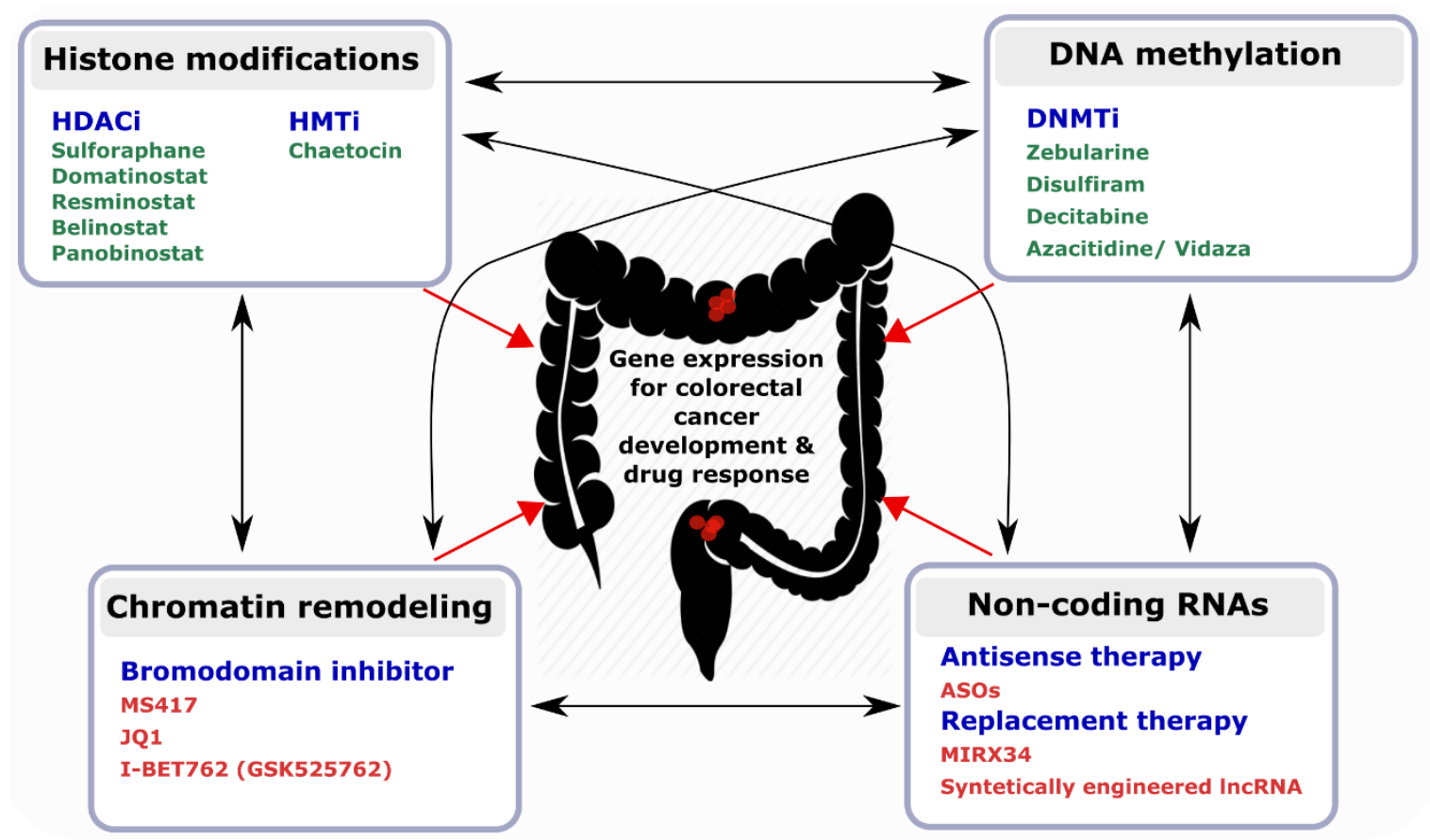

Figure 3. Representative drugs targeting epigenetic modifiers. Green colour represents FDA-approved drugs and red colour represents other potential drugs for targeting epigenetics modifiers. Black arrows indicate the reciprocal interplay of epigenetic events with ncRNAs and red arrows represent their effects on the CRC genome and transcriptome.

\section{Future Directions}

Colorectal cancer arises in a stepwise mode from either discrete genetic alterations or epigenetic perturbations. Multiple epigenetic mechanisms, including DNA methylation, histone modifications, chromatin remodelling and non-coding RNAs are all involved in CRC pathogenesis. Among these, lncRNAs are emerging as highly versatile players in diverse biological processes regulating gene expression at the epigenetic-, transcriptional, as well as post-transcriptional levels. Although ncRNAs reveal new layers of gene-regulatory complexity, with advances in technologies such as next-generation sequencing and CRISPR, their functions will be gradually deciphered. Of note, recent findings reveal that epitranscriptomic modifications of lncRNAs, such as N6-methyladenosine (m6A), pseudouridine

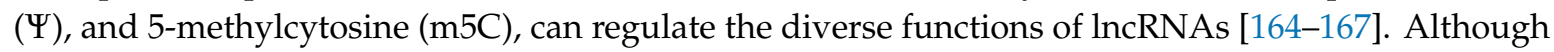
epitranscriptomics adds yet another layer of complexity, it may also provide new opportunities for discovering enhanced biomarkers or therapeutic approaches. However, the field of RNA modifications is still in its infancy and much groundwork remains to be done.

In this context, many recent studies have demonstrated the power of diverse CRISPR technologies to decipher the roles of epigenetic modulators, modifiers and mediators in CRC. The CRISPR/Cas9 system has been used for multiplexed knockout screens of epigenetic regulators $[47,168]$. Another derivate, the CRISPR/deadCas9 system, in which the nuclease activity of Cas9 has been deactivated, can still specifically target any dsDNA sequence through the design of a specific guide RNA. The dead Cas9 system has been adapted to target transcriptional repressors (CRISPRi) and activators (CRISPRa) [169]. Examples are CRISPR/dCas9-VPR for the transcriptional activation of fucosyl transferase (FUT) genes [170], DICaS (genome-wide dual protein-coding and non-coding integrated CRISPRa screening) to identify coding and lncRNA genes involved in drug resistance mechanisms [171] and CRISPR/dCas9-KRAB for HS2 enhancer repression [172,173]. Furthermore, the dead Cas9 system can be used for efficient, directed manipulation of the epigenome via fusion with epi-effector enzymes such as the catalytic domains of TET1 for selective DNA demethylation [174], or DNA methyltransferase 
DNMT3A for targeted CpG methylation of gene promoters [175]. Dead Cas9 has also been used for targeted localization of lncRNAs to specific genomic loci [176].

Moreover, the CRISPR/Cas9 technology could significantly reduce side effects of epigenetic drugs by targeting them specifically to modulate genes of interest.

Lastly, it requires integrative approaches such as system biology to fully understand gene regulation in CRC by means of epigenetics, alternative splicing, and ncRNAs. The complexity of gene regulation realized by these mechanisms is difficult to comprehend and demands the aid of computer models $[177,178]$. Spatial models of the intestinal crypts and colorectal cancer development have been reviewed by De Matteis et al. [179]. Recently, a computational model was developed, linking cell surface receptor (EGFR) activation, the MAPK signalling pathway and tumour growth to determine whether ERK inhibitor drugs may be of benefit for CRC patients with the frequently occurring BRAF ${ }^{\mathrm{V} 600 \mathrm{E}}$ mutation [180]. Vafaee et al. have integrated data-driven and knowledge-based approaches for biomarker identification in CRC and thereby identified a plasma miRNA signature that is predictive of patients' survival outcome [181]. To date, however, very few studies have integrated epigenetics and alternative splicing into their models of cancer gene regulation.

Supplementary Materials: Table S1 and Figure S1 are available online at http://www.mdpi.com/2073-4409/8/8/929/ s1. Table S1: LncRNAs sponging microRNAs in CRC. Figure S1: Overview of cross-talk between gene-regulatory layers in CRC (A vector graphics version).

Funding: We would like to acknowledge the following funding sources: the Cancer Research UK (CRUK) International Accelerator programme (ACRCelerate; RA, PDD); the joint Medical Research Council (MRC) and CRUK Colorectal Cancer Stratified Medicine Programme Grant (S:CORT; PDD). US is supported by a Fellowship from the Cancer Institute NSW. This manuscript reflects the views of the authors and may not reflect the opinions or views of the funder of the S:CORT consortium.

Conflicts of Interest: The authors have no conflict of interests.

\section{References}

1. Shen, H.; Laird, P.W. Interplay between the cancer genome and epigenome. Cell 2013, 153, 38-55. [CrossRef] [PubMed]

2. Assenov, Y.; Brocks, D.; Gerhauser, C. Intratumor heterogeneity in epigenetic patterns. Semin. Cancer Biol. 2018, 51, 12-21. [CrossRef] [PubMed]

3. Vaiopoulos, A.G.; Athanasoula, K.; Papavassiliou, A.G. Epigenetic modifications in colorectal cancer: Molecular insights and therapeutic challenges. Biochim. Biophys. Acta 2014, 1842, 971-980. [CrossRef] [PubMed]

4. Migliore, L.; Migheli, F.; Spisni, R.; Coppede, F. Genetics, cytogenetics, and epigenetics of colorectal cancer. J. Biomed. Biotechnol. 2011, 2011, 792362. [CrossRef] [PubMed]

5. Guinney, J.; Dienstmann, R.; Wang, X.; de Reynies, A.; Schlicker, A.; Soneson, C.; Marisa, L.; Roepman, P.; Nyamundanda, G.; Angelino, P.; et al. The consensus molecular subtypes of colorectal cancer. Nat. Med. 2015, 21, 1350-1356. [CrossRef] [PubMed]

6. Nguyen, H.T.; Duong, H.Q. The molecular characteristics of colorectal cancer: Implications for diagnosis and therapy. Oncol. Lett. 2018, 16, 9-18. [CrossRef] [PubMed]

7. Hong, S.N. Genetic and epigenetic alterations of colorectal cancer. Intest. Res. 2018, 16, 327-337. [CrossRef] [PubMed]

8. Zeng, K.; Chen, X.; Hu, X.; Liu, X.; Xu, T.; Sun, H.; Pan, Y.; He, B.; Wang, S. Lactb, a novel epigenetic silenced tumor suppressor, inhibits colorectal cancer progression by attenuating MDM2-mediated p53 ubiquitination and degradation. Oncogene 2018, 37, 5534-5551. [CrossRef] [PubMed]

9. Feinberg, A.P.; Koldobskiy, M.A.; Gondor, A. Epigenetic modulators, modifiers and mediators in cancer aetiology and progression. Nat. Rev. Genet. 2016, 17, 284-299. [CrossRef] [PubMed]

10. Martinez-Cardus, A.; Moran, S.; Musulen, E.; Moutinho, C.; Manzano, J.L.; Martinez-Balibrea, E.; Tierno, M.; Elez, E.; Landolfi, S.; Lorden, P.; et al. Epigenetic homogeneity within colorectal tumors predicts shorter relapse-free and overall survival times for patients with locoregional cancer. Gastroenterology 2016, 151, 961-972. [CrossRef] 
11. Widschwendter, M.; Fiegl, H.; Egle, D.; Mueller-Holzner, E.; Spizzo, G.; Marth, C.; Weisenberger, D.J.; Campan, M.; Young, J.; Jacobs, I.; et al. Epigenetic stem cell signature in cancer. Nat. Genet. 2007, 39, 157-158. [CrossRef] [PubMed]

12. Chen, Y.C.; Gotea, V.; Margolin, G.; Elnitski, L. Significant associations between driver gene mutations and DNA methylation alterations across many cancer types. PLoS Comput. Biol. 2017, 13, e1005840. [CrossRef] [PubMed]

13. Hinoue, T.; Weisenberger, D.J.; Pan, F.; Campan, M.; Kim, M.; Young, J.; Whitehall, V.L.; Leggett, B.A.; Laird, P.W. Analysis of the association between CIMP and BRAF in colorectal cancer by DNA methylation profiling. PLoS ONE 2009, 4, e8357. [CrossRef] [PubMed]

14. Yamamoto, E.; Suzuki, H.; Yamano, H.O.; Maruyama, R.; Nojima, M.; Kamimae, S.; Sawada, T.; Ashida, M.; Yoshikawa, K.; Kimura, T.; et al. Molecular dissection of premalignant colorectal lesions reveals early onset of the CPG island methylator phenotype. Am. J. Pathol. 2012, 181, 1847-1861. [CrossRef] [PubMed]

15. Hanahan, D.; Weinberg, R.A. Hallmarks of cancer: The next generation. Cell 2011, 144, 646-674. [CrossRef] [PubMed]

16. Chang, P.Y.; Chen, J.S.; Chang, S.C.; Wang, M.C.; Chang, N.C.; Wen, Y.H.; Tsai, W.S.; Liu, W.H.; Liu, H.L.; Lu, J.J. Acquired somatic TP53 or PIK3CA mutations are potential predictors of when polyps evolve into colorectal cancer. Oncotarget 2017, 8, 72352-72362. [CrossRef] [PubMed]

17. Allis, C.D.; Jenuwein, T. The molecular hallmarks of epigenetic control. Nat. Rev. Genet. 2016, 17, 487-500. [CrossRef] [PubMed]

18. Baylin, S.B.; Jones, P.A. Epigenetic determinants of cancer. Cold Spring Harb. Perspect. Biol. 2016, 8, a019505. [CrossRef] [PubMed]

19. Liu, Y.H.; Li, Y.; Liu, X.H.; Sui, H.M.; Liu, Y.X.; Xiao, Z.Q.; Zheng, P.; Chen, L.; Yao, S.; Xing, C.; et al. A signature for induced pluripotent stem cell-associated genes in colorectal cancer. Med. Oncol. 2013, 30, 426. [CrossRef]

20. Mathonnet, M.; Perraud, A.; Christou, N.; Akil, H.; Melin, C.; Battu, S.; Jauberteau, M.O.; Denizot, Y. Hallmarks in colorectal cancer: Angiogenesis and cancer stem-like cells. World J. Gastroenterol. 2014, 20, 4189-4196. [CrossRef]

21. Matano, M.; Date, S.; Shimokawa, M.; Takano, A.; Fujii, M.; Ohta, Y.; Watanabe, T.; Kanai, T.; Sato, T. Modeling colorectal cancer using crispr-cas9-mediated engineering of human intestinal organoids. Nat. Med. 2015, 21, 256-262. [CrossRef] [PubMed]

22. Drost, J.; van Jaarsveld, R.H.; Ponsioen, B.; Zimberlin, C.; van Boxtel, R.; Buijs, A.; Sachs, N.; Overmeer, R.M.; Offerhaus, G.J.; Begthel, H.; et al. Sequential cancer mutations in cultured human intestinal stem cells. Nature 2015, 521, 43-47. [CrossRef] [PubMed]

23. Fumagalli, A.; Drost, J.; Suijkerbuijk, S.J.; van Boxtel, R.; de Ligt, J.; Offerhaus, G.J.; Begthel, H.; Beerling, E.; Tan, E.H.; Sansom, O.J.; et al. Genetic dissection of colorectal cancer progression by orthotopic transplantation of engineered cancer organoids. PNAS 2017, 114, E2357-E2364. [CrossRef] [PubMed]

24. Lannagan, T.R.M.; Lee, Y.K.; Wang, T.; Roper, J.; Bettington, M.L.; Fennell, L.; Vrbanac, L.; Jonavicius, L.; Somashekar, R.; Gieniec, K.; et al. Genetic editing of colonic organoids provides a molecularly distinct and orthotopic preclinical model of serrated carcinogenesis. Gut 2019, 68, 684-692. [CrossRef] [PubMed]

25. Fang, M.; Ou, J.; Hutchinson, L.; Green, M.R. The braf oncoprotein functions through the transcriptional repressor MAFG to mediate the CPG island methylator phenotype. Mol. Cell 2014, 55, 904-915. [CrossRef] [PubMed]

26. Fennell, L.; Dumenil, T.; Wockner, L.; Hartel, G.; Nones, K.; Bond, C.; Borowsky, J.; Liu, C.; McKeone, D.; Bowdler, L.; et al. Integrative genome-scale DNA methylation analysis of a large and unselected cohort reveals five distinct subtypes of colorectal adenocarcinomas. Cell. Mol. Gastroenterol. Hepatol. 2019, 8, 269-290. [CrossRef] [PubMed]

27. Serra, R.W.; Fang, M.; Park, S.M.; Hutchinson, L.; Green, M.R. A kras-directed transcriptional silencing pathway that mediates the CPG island methylator phenotype. Elife 2014, 3, e02313. [CrossRef] [PubMed]

28. De Craene, B.; Berx, G. Regulatory networks defining EMT during cancer initiation and progression. Nat. Rev. Cancer 2013, 13, 97-110. [CrossRef] [PubMed]

29. Nebbioso, A.; Tambaro, F.P.; Dell'Aversana, C.; Altucci, L. Cancer epigenetics: Moving forward. PLoS Genet. 2018, 14, e1007362. [CrossRef] 
30. Plass, C.; Pfister, S.M.; Lindroth, A.M.; Bogatyrova, O.; Claus, R.; Lichter, P. Mutations in regulators of the epigenome and their connections to global chromatin patterns in cancer. Nat. Rev. Genet. 2013, 14, 765-780. [CrossRef]

31. Pfister, S.X.; Ashworth, A. Marked for death: Targeting epigenetic changes in cancer. Nat. Rev. Drug Discov. 2017, 16, 241-263. [CrossRef]

32. Lizarbe, M.A.; Calle-Espinosa, J.; Fernandez-Lizarbe, E.; Fernandez-Lizarbe, S.; Robles, M.A.; Olmo, N.; Turnay, J. Colorectal cancer: From the genetic model to posttranscriptional regulation by noncoding RNAs. Biomed. Res. Int. 2017, 2017, 7354260. [CrossRef]

33. Han, D.; Wang, M.; Ma, N.; Xu, Y.; Jiang, Y.; Gao, X. Long noncoding RNAs: Novel players in colorectal cancer. Cancer Lett. 2015, 361, 13-21. [CrossRef]

34. Kim, T.; Croce, C.M. Long noncoding RNAs: Undeciphered cellular codes encrypting keys of colorectal cancer pathogenesis. Cancer Lett. 2018, 417, 89-95. [CrossRef]

35. Li, H.; Ma, S.Q.; Huang, J.; Chen, X.P.; Zhou, H.H. Roles of long noncoding RNAs in colorectal cancer metastasis. Oncotarget 2017, 8, 39859-39876. [CrossRef]

36. Schmitz, U.; Naderi-Meshkin, H.; Gupta, S.K.; Wolkenhauer, O.; Vera, J. The RNA world in the 21st century-a systems approach to finding non-coding keys to clinical questions. Brief. Bioinform. 2016, 17, 380-392. [CrossRef]

37. Wu, L.; Murat, P.; Matak-Vinkovic, D.; Murrell, A.; Balasubramanian, S. Binding interactions between long noncoding RNA HOTAIR and PRC2 proteins. Biochemistry 2013, 52, 9519-9527. [CrossRef]

38. Wang, K.; Jin, W.; Song, Y.; Fei, X. Lncrna rp11-436h11.5, functioning as a competitive endogenous Rna, upregulates bcl-w expression by sponging mir-335-5p and promotes proliferation and invasion in renal cell carcinoma. Mol. Cancer 2017, 16, 166. [CrossRef]

39. Neve, B.; Jonckheere, N.; Vincent, A.; Van Seuningen, I. Epigenetic regulation by lncRNAs: An overview focused on uca1 in colorectal cancer. Cancers 2018, 10, 440. [CrossRef]

40. Liu, T.; Han, Z.; Li, H.; Zhu, Y.; Sun, Z.; Zhu, A. Lncrna dleu1 contributes to colorectal cancer progression via activation of KPNA3. Mol. Cancer 2018, 17, 118. [CrossRef]

41. Dienstmann, R.; Vermeulen, L.; Guinney, J.; Kopetz, S.; Tejpar, S.; Tabernero, J. Consensus molecular subtypes and the evolution of precision medicine in colorectal cancer. Nat. Rev. Cancer 2017, 17, 79-92. [CrossRef]

42. Liu, Y.; Sethi, N.S.; Hinoue, T.; Schneider, B.G.; Cherniack, A.D.; Sanchez-Vega, F.; Seoane, J.A.; Farshidfar, F.; Bowlby, R.; Islam, M.; et al. Comparative molecular analysis of gastrointestinal adenocarcinomas. Cancer Cell 2018, 33, 721-735.e8. [CrossRef]

43. Matsuzaki, K.; Deng, G.; Tanaka, H.; Kakar, S.; Miura, S.; Kim, Y.S. The relationship between global methylation level, loss of heterozygosity, and microsatellite instability in sporadic colorectal cancer. Clin. Cancer Res. 2005, 11, 8564-8569. [CrossRef]

44. Deng, G.; Nguyen, A.; Tanaka, H.; Matsuzaki, K.; Bell, I.; Mehta, K.R.; Terdiman, J.P.; Waldman, F.M.; Kakar, S.; Gum, J.; et al. Regional hypermethylation and global hypomethylation are associated with altered chromatin conformation and histone acetylation in colorectal cancer. Int. J. Cancer 2006, 118, 2999-3005. [CrossRef]

45. Nazemalhosseini Mojarad, E.; Kuppen, P.J.; Aghdaei, H.A.; Zali, M.R. The cpg island methylator phenotype (CIMP) in colorectal cancer. Gastroenterol Hepatol. Bed. Bench. 2013, 6, 120-128.

46. Rokavec, M.; Horst, D.; Hermeking, H. Cellular model of colon cancer progression reveals signatures of mRNAs, miRNA, lncRNAs, and epigenetic modifications associated with metastasis. Cancer Res. 2017, 77, 1854-1867. [CrossRef]

47. McCleland, M.L.; Mesh, K.; Lorenzana, E.; Chopra, V.S.; Segal, E.; Watanabe, C.; Haley, B.; Mayba, O.; Yaylaoglu, M.; Gnad, F.; et al. CCAT1 is an enhancer-templated RNA that predicts BET sensitivity in colorectal cancer. J. Clin. Investig. 2016, 126, 639-652. [CrossRef]

48. Mio, C.; Bulotta, S.; Russo, D.; Damante, G. Reading cancer: Chromatin readers as druggable targets for cancer treatment. Cancers 2019, 11, 61. [CrossRef]

49. Merry, C.R.; Forrest, M.E.; Sabers, J.N.; Beard, L.; Gao, X.H.; Hatzoglou, M.; Jackson, M.W.; Wang, Z.; Markowitz, S.D.; Khalil, A.M. DNMT1-associated long non-coding RNAs regulate global gene expression and DNA methylation in colon cancer. Hum. Mol. Genet. 2015, 24, 6240-6253. [CrossRef] 
50. Somasundaram, S.; Forrest, M.E.; Moinova, H.; Cohen, A.; Varadan, V.; LaFramboise, T.; Markowitz, S.; Khalil, A.M. The dnmt1-associated lincrna dacor1 reprograms genome-wide DNA methylation in colon cancer. Clin. Epigenet. 2018, 10, 127. [CrossRef]

51. Uribe-Lewis, S.; Stark, R.; Carroll, T.; Dunning, M.J.; Bachman, M.; Ito, Y.; Stojic, L.; Halim, S.; Vowler, S.L.; Lynch, A.G.; et al. 5-hydroxymethylcytosine marks promoters in colon that resist DNA hypermethylation in cancer. Genome Biol. 2015, 16, 69. [CrossRef]

52. Tian, Y.; Pan, F.; Sun, X.; Gan, M.; Lin, A.; Zhang, D.; Zhu, Y.; Lai, M. Association of tet1 expression with colorectal cancer progression. Scand. J. Gastroenterol. 2017, 52, 312-320. [CrossRef]

53. Hu, H.; Shu, M.; He, L.; Yu, X.; Liu, X.; Lu, Y.; Chen, Y.; Miao, X.; Chen, X. Epigenomic landscape of 5-hydroxymethylcytosine reveals its transcriptional regulation of LncRNAs in colorectal cancer. Br. J. Cancer 2017, 116, 658-668. [CrossRef]

54. Puig, I.; Tenbaum, S.P.; Chicote, I.; Arques, O.; Martinez-Quintanilla, J.; Cuesta-Borras, E.; Ramirez, L.; Gonzalo, P.; Soto, A.; Aguilar, S.; et al. TET2 controls chemoresistant slow-cycling cancer cell survival and tumor recurrence. J. Clin. Investig. 2018, 128, 3887-3905. [CrossRef]

55. Mitrea, C.; Wijesinghe, P.; Dyson, G.; Kruger, A.; Ruden, D.M.; Draghici, S.; Bollig-Fischer, A. Integrating $5 \mathrm{hmc}$ and gene expression data to infer regulatory mechanisms. Bioinformatics 2018, 34, 1441-1447. [CrossRef]

56. Lin, J.; Shi, Z.; Yu, Z.; He, Z. LncRNA HIF1A-AS2 positively affects the progression and EMT formation of colorectal cancer through regulating miR-129-5p and DNMT3A. Biomed. Pharmacother. 2018, 98, 433-439. [CrossRef]

57. Han, L.; Witmer, P.D.; Casey, E.; Valle, D.; Sukumar, S. DNA methylation regulates microRNA expression. Cancer Biol. Ther. 2007, 6, 1284-1288. [CrossRef]

58. Shi, L.; Li, X.; Wu, Z.; Nie, J.; Guo, M.; Mei, Q.; Han, W. DNA methylation-mediated repression of $\mathrm{miR}-181 \mathrm{a} / 135 \mathrm{a} / 302 \mathrm{c}$ expression promotes the microsatellite-unstable colorectal cancer development and 5-FU resistance via targeting PLAG1. J. Genet. Genom. 2018, 45, 205-214. [CrossRef]

59. Qin, J.; Ke, J.; Xu, J.; Wang, F.; Zhou, Y.; Jiang, Y.; Wang, Z. Downregulation of microRNA-132 by DNA hypermethylation is associated with cell invasion in colorectal cancer. Oncotargets Ther. 2015, 8, 3639-3648.

60. Lv, L.V.; Zhou, J.; Lin, C.; Hu, G.; Yi, L.U.; Du, J.; Gao, K.; Li, X. DNA methylation is involved in the aberrant expression of miR-133b in colorectal cancer cells. Oncol. Lett. 2015, 10, 907-912. [CrossRef]

61. To, K.K.; Leung, W.W.; Ng, S.S. A novel miR-203-DNMT3b-ABCG2 regulatory pathway predisposing colorectal cancer development. Mol. Carcinog. 2017, 56, 464-477. [CrossRef]

62. Tian, F.; Tang, Z.; Song, G.; Pan, Y.; He, B.; Bao, Q.; Wang, S. Loss of imprinting of IGF2 correlates with hypomethylation of the $\mathrm{H} 19$ differentially methylated region in the tumor tissue of colorectal cancer patients. Mol. Med. Rep. 2012, 5, 1536-1540.

63. Cui, H.; Onyango, P.; Brandenburg, S.; Wu, Y.; Hsieh, C.L.; Feinberg, A.P. Loss of imprinting in colorectal cancer linked to hypomethylation of H19 and IGF2. Cancer Res. 2002, 62, 6442-6446.

64. Cheng, Y.W.; Idrees, K.; Shattock, R.; Khan, S.A.; Zeng, Z.; Brennan, C.W.; Paty, P.; Barany, F. Loss of imprinting and marked gene elevation are 2 forms of aberrant IGF2 expression in colorectal cancer. Int. J. Cancer 2010, 127, 568-577. [CrossRef]

65. Wang, X.; Bu, J.; Liu, X.; Wang, W.; Mai, W.; Lv, B.; Zou, J.; Mo, X.; Li, X.; Wang, J.; et al. miR-133b suppresses metastasis by targeting HOXA9 in human colorectal cancer. Oncotarget 2017, 8, 63935-63948. [CrossRef]

66. Ren, S.; Wang, F.; Shen, J.; Sun, Y.; Xu, W.; Lu, J.; Wei, M.; Xu, C.; Wu, C.; Zhang, Z.; et al. Long non-coding rna metastasis associated in lung adenocarcinoma transcript 1 derived miniRNA as a novel plasma-based biomarker for diagnosing prostate cancer. Eur. J. Cancer 2013, 49, 2949-2959. [CrossRef]

67. Tang, J.T.; Wang, J.L.; Du, W.; Hong, J.; Zhao, S.L.; Wang, Y.C.; Xiong, H.; Chen, H.M.; Fang, J.Y. Microrna 345, a methylation-sensitive microRNA is involved in cell proliferation and invasion in human colorectal cancer. Carcinogenesis 2011, 32, 1207-1215. [CrossRef]

68. Ling, H.; Spizzo, R.; Atlasi, Y.; Nicoloso, M.; Shimizu, M.; Redis, R.S.; Nishida, N.; Gafa, R.; Song, J.; Guo, Z.; et al. CCAT2, a novel noncoding RNA mapping to 8q24, underlies metastatic progression and chromosomal instability in colon cancer. Genome Res. 2013, 23, 1446-1461. [CrossRef]

69. Kasagi, Y.; Oki, E.; Ando, K.; Ito, S.; Iguchi, T.; Sugiyama, M.; Nakashima, Y.; Ohgaki, K.; Saeki, H.; Mimori, K.; et al. The expression of CCAT2, a novel long noncoding RNA transcript, and rs6983267 single-nucleotide polymorphism genotypes in colorectal cancers. Oncology 2017, 92, 48-54. [CrossRef] 
70. Xiang, J.F.; Yin, Q.F.; Chen, T.; Zhang, Y.; Zhang, X.O.; Wu, Z.; Zhang, S.; Wang, H.B.; Ge, J.; Lu, X.; et al. Human colorectal cancer-specific CCAT1-1 LncRNA regulates long-range chromatin interactions at the MYC locus. Cell Res. 2014, 24, 513-531. [CrossRef]

71. Ozawa, T.; Matsuyama, T.; Toiyama, Y.; Takahashi, N.; Ishikawa, T.; Uetake, H.; Yamada, Y.; Kusunoki, M.; Calin, G.; Goel, A. CCAT1 and CCAT2 long noncoding rNAS, located within the 8q.24.21 'gene desert', serve as important prognostic biomarkers in colorectal cancer. Ann. Oncol. 2017, 28, 1882-1888. [CrossRef]

72. Kogo, R.; Shimamura, T.; Mimori, K.; Kawahara, K.; Imoto, S.; Sudo, T.; Tanaka, F.; Shibata, K.; Suzuki, A.; Komune, S.; et al. Long noncoding rna hotair regulates polycomb-dependent chromatin modification and is associated with poor prognosis in colorectal cancers. Cancer Res. 2011, 71, 6320-6326. [CrossRef]

73. Chen, X.; Liu, B.; Yang, R.; Guo, Y.; Li, F.; Wang, L.; Hu, H. Integrated analysis of long non-coding rNAS in human colorectal cancer. Oncotarget 2016, 7, 23897-23908. [CrossRef]

74. Xu, M.; Chen, X.; Lin, K.; Zeng, K.; Liu, X.; Pan, B.; Xu, X.; Xu, T.; Hu, X.; Sun, L.; et al. The long noncoding rna snhg1 regulates colorectal cancer cell growth through interactions with EZH2 and miR-154-5p. Mol. Cancer 2018, 17, 141. [CrossRef]

75. Ding, J.; Li, J.; Wang, H.; Tian, Y.; Xie, M.; He, X.; Ji, H.; Ma, Z.; Hui, B.; Wang, K.; et al. Long noncoding RNA crnde promotes colorectal cancer cell proliferation via epigenetically silencing DUSP5/CDKN1a expression. Cell Death Dis. 2017, 8, e2997. [CrossRef]

76. Syn, N.; Wang, L.; Sethi, G.; Thiery, J.P.; Goh, B.C. Exosome-mediated metastasis: From epithelial-mesenchymal transition to escape from immunosurveillance. Trends Pharmacol. Sci. 2016, 37, 606-617. [CrossRef]

77. Wang, L.; Bu, P.; Ai, Y.; Srinivasan, T.; Chen, H.J.; Xiang, K.; Lipkin, S.M.; Shen, X. A long non-coding RNA targets microrna miR-34a to regulate colon cancer stem cell asymmetric division. Elife 2016, 5, e14620. [CrossRef]

78. Li, A.X.; Xin, W.Q.; Ma, C.G. Fentanyl inhibits the invasion and migration of colorectal cancer cells via inhibiting the negative regulation of ETS-1 on bancr. Biochem. Biophys. Res. Commun. 2015, 465, 594-600. [CrossRef]

79. Alaiyan, B.; Ilyayev, N.; Stojadinovic, A.; Izadjoo, M.; Roistacher, M.; Pavlov, V.; Tzivin, V.; Halle, D.; Pan, H.; Trink, B.; et al. Differential expression of colon cancer associated transcript1 (CCAT1) along the colonic adenoma-carcinoma sequence. BMC Cancer 2013, 13, 196. [CrossRef]

80. Li, P.; Zhang, X.; Wang, H.; Wang, L.; Liu, T.; Du, L.; Yang, Y.; Wang, C. MALAT1 is associated with poor response to oxaliplatin-based chemotherapy in colorectal cancer patients and promotes chemoresistance through EZH2. Mol. Cancer Ther. 2017, 16, 739-751. [CrossRef]

81. Yang, X.J.; Huang, C.Q.; Peng, C.W.; Hou, J.X.; Liu, J.Y. Long noncoding RNA HULC promotes colorectal carcinoma progression through epigenetically repressing NKD2 expression. Gene 2016, 592, $172-178$. [CrossRef]

82. Ma, Z.; Gu, S.; Song, M.; Yan, C.; Hui, B.; Ji, H.; Wang, J.; Zhang, J.; Wang, K.; Zhao, Q. Long non-coding RNA SNHG17 is an unfavourable prognostic factor and promotes cell proliferation by epigenetically silencing p57 in colorectal cancer. Mol. Biosyst. 2017, 13, 2350-2361. [CrossRef]

83. Ma, Z.; Peng, P.; Zhou, J.; Hui, B.; Ji, H.; Wang, J.; Wang, K. Long non-coding RNA SH3PXD2A-AS1 promotes cell progression partly through epigenetic silencing p57 and KLF2 in colorectal cancer. Cell. Physiol. Biochem. 2018, 46, 2197-2214. [CrossRef]

84. Li, Z.; Qiu, R.; Qiu, X.; Tian, T. SNHG6 promotes tumor growth via repression of p21 in colorectal cancer. Cell. Physiol. Biochem. 2018, 49, 463-478. [CrossRef]

85. Zhu, Y.; Chen, P.; Gao, Y.; Ta, N.; Zhang, Y.; Cai, J.; Zhao, Y.; Liu, S.; Zheng, J. MEG3 activated by vitamin d inhibits colorectal cancer cells proliferation and migration via regulating clusterin. EBioMedicine 2018, 30, 148-157. [CrossRef]

86. Marin-Bejar, O.; Marchese, F.P.; Athie, A.; Sanchez, Y.; Gonzalez, J.; Segura, V.; Huang, L.; Moreno, I.; Navarro, A.; Monzo, M.; et al. Pint LincRNA connects the p53 pathway with epigenetic silencing by the polycomb repressive complex 2. Genome Biol. 2013, 14, R104. [CrossRef]

87. Marin-Bejar, O.; Mas, A.M.; Gonzalez, J.; Martinez, D.; Athie, A.; Morales, X.; Galduroz, M.; Raimondi, I.; Grossi, E.; Guo, S.; et al. The human lncrna linc-pint inhibits tumor cell invasion through a highly conserved sequence element. Genome Biol. 2017, 18, 202. [CrossRef] 
88. Huang, W.; Su, G.; Huang, X.; Zou, A.; Wu, J.; Yang, Y.; Zhu, Y.; Liang, S.; Li, D.; Ma, F.; et al. Long noncoding rna pcat6 inhibits colon cancer cell apoptosis by regulating anti-apoptotic protein arc expression via EZH2. Cell Cycle 2019, 18, 69-83. [CrossRef]

89. Li, T.; Xu, C.; Cai, B.; Zhang, M.; Gao, F.; Gan, J. Expression and clinicopathological significance of the LncRNA HOXA11-as in colorectal cancer. Oncol. Lett. 2016, 12, 4155-4160. [CrossRef]

90. Sun, M.; Nie, F.; Wang, Y.; Zhang, Z.; Hou, J.; He, D.; Xie, M.; Xu, L.; De, W.; Wang, Z.; et al. LncRNA HOXA11-as promotes proliferation and invasion of gastric cancer by scaffolding the chromatin modification factors PRC2, LSD1, and DNMT1. Cancer Res. 2016, 76, 6299-6310. [CrossRef]

91. Bisognin, A.; Pizzini, S.; Perilli, L.; Esposito, G.; Mocellin, S.; Nitti, D.; Zanovello, P.; Bortoluzzi, S.; Mandruzzato, S. An integrative framework identifies alternative splicing events in colorectal cancer development. Mol. Oncol. 2014, 8, 129-141. [CrossRef]

92. Zong, Z.; Li, H.; Yi, C.; Ying, H.; Zhu, Z.; Wang, H. Genome-wide profiling of prognostic alternative splicing signature in colorectal cancer. Front. Oncol. 2018, 8, 537. [CrossRef]

93. Xiong, Y.; Deng, Y.; Wang, K.; Zhou, H.; Zheng, X.; Si, L.; Fu, Z. Profiles of alternative splicing in colorectal cancer and their clinical significance: A study based on large-scale sequencing data. EBioMedicine 2018, 36, 183-195. [CrossRef]

94. Liu, J.; Li, H.; Shen, S.; Sun, L.; Yuan, Y.; Xing, C. Alternative splicing events implicated in carcinogenesis and prognosis of colorectal cancer. J. Cancer 2018, 9, 1754-1764. [CrossRef]

95. Kahles, A.; Lehmann, K.V.; Toussaint, N.C.; Huser, M.; Stark, S.G.; Sachsenberg, T.; Stegle, O.; Kohlbacher, O.; Sander, C.; Ratsch, G. Comprehensive analysis of alternative splicing across tumors from 8,705 patients. Cancer Cell 2018, 34, 211-224.e6. [CrossRef]

96. Eilertsen, I.A.; Sveen, A.; Stromme, J.M.; Skotheim, R.I.; Nesbakken, A.; Lothe, R.A. Alternative splicing expands the prognostic impact of KRAS in microsatellite stable primary colorectal cancer. Int. J. Cancer 2019, 144, 841-847. [CrossRef]

97. Sebestyen, E.; Singh, B.; Minana, B.; Pages, A.; Mateo, F.; Pujana, M.A.; Valcarcel, J.; Eyras, E. Large-scale analysis of genome and transcriptome alterations in multiple tumors unveils novel cancer-relevant splicing networks. Genome Res. 2016, 26, 732-744. [CrossRef]

98. Ghigna, C.; Giordano, S.; Shen, H.; Benvenuto, F.; Castiglioni, F.; Comoglio, P.M.; Green, M.R.; Riva, S.; Biamonti, G. Cell motility is controlled by SF2/ASF through alternative splicing of the RON protooncogene. Mol. Cell 2005, 20, 881-890. [CrossRef]

99. Thorsen, K.; Mansilla, F.; Schepeler, T.; Oster, B.; Rasmussen, M.H.; Dyrskjot, L.; Karni, R.; Akerman, M.; Krainer, A.R.; Laurberg, S.; et al. Alternative splicing of SLC39A14 in colorectal cancer is regulated by the wnt pathway. Mol. Cell. Proteom. 2011, 10, M110-002998. [CrossRef]

100. Goncalves, V.; Henriques, A.F.; Pereira, J.F.; Neves Costa, A.; Moyer, M.P.; Moita, L.F.; Gama-Carvalho, M.; Matos, P.; Jordan, P. Phosphorylation of SRSF1 by SRPK1 regulates alternative splicing of tumor-related rac1b in colorectal cells. RNA 2014, 20, 474-482. [CrossRef]

101. Cohen-Eliav, M.; Golan-Gerstl, R.; Siegfried, Z.; Andersen, C.L.; Thorsen, K.; Orntoft, T.F.; Mu, D.; Karni, R. The splicing factor SRSF6 is amplified and is an oncoprotein in lung and colon cancers. J. Pathol. 2013, 229, 630-639. [CrossRef]

102. Neklason, D.W.; Solomon, C.H.; Dalton, A.L.; Kuwada, S.K.; Burt, R.W. Intron 4 mutation in APC gene results in splice defect and attenuated FAP phenotype. Fam. Cancer 2004, 3, 35-40. [CrossRef]

103. McVety, S.; Li, L.; Gordon, P.H.; Chong, G.; Foulkes, W.D. Disruption of an exon splicing enhancer in exon 3 of MLH1 is the cause of HNPCC in a quebec family. J. Med Genet. 2006, 43, 153-156. [CrossRef]

104. Goncalves, V.; Theisen, P.; Antunes, O.; Medeira, A.; Ramos, J.S.; Jordan, P.; Isidro, G. A missense mutation in the apc tumor suppressor gene disrupts an ASF/SF2 splicing enhancer motif and causes pathogenic skipping of exon 14. Mutat. Res. 2009, 662, 33-36. [CrossRef]

105. Urbanski, L.M.; Leclair, N.; Anczukow, O. Alternative-splicing defects in cancer: Splicing regulators and their downstream targets, guiding the way to novel cancer therapeutics. Wiley Interdiscip. Rev. RNA 2018, 9, e1476. [CrossRef]

106. Lin, J.C.; Lee, Y.C.; Liang, Y.C.; Fann, Y.C.; Johnson, K.R.; Lin, Y.J. The impact of the rbm4-initiated splicing cascade on modulating the carcinogenic signature of colorectal cancer cells. Sci. Rep. 2017, 7, 44204 . [CrossRef] 
107. Lin, J.C.; Lee, Y.C.; Tan, T.H.; Liang, Y.C.; Chuang, H.C.; Fann, Y.C.; Johnson, K.R.; Lin, Y.J. RBM4-SRSF3-MAP4K4 splicing cascade modulates the metastatic signature of colorectal cancer cell. Biochim. Biophys. Acta. Mol. Cell Res. 2018, 1865, 259-272. [CrossRef]

108. Wiencke, J.K.; Zheng, S.; Morrison, Z.; Yeh, R.F. Differentially expressed genes are marked by histone 3 lysine 9 trimethylation in human cancer cells. Oncogene 2008, 27, 2412-2421. [CrossRef]

109. Riffo-Campos, A.L.; Gimeno-Valiente, F.; Rodriguez, F.M.; Cervantes, A.; Lopez-Rodas, G.; Franco, L.; Castillo, J. Role of epigenetic factors in the selection of the alternative splicing isoforms of human KRAS in colorectal cancer cell lines. Oncotarget 2018, 9, 20578-20589. [CrossRef]

110. Matveeva, E.A.; Al-Tinawi, Q.M.H.; Rouchka, E.C.; Fondufe-Mittendorf, Y.N. Coupling of PARP1-mediated chromatin structural changes to transcriptional RNA polymerase ii elongation and cotranscriptional splicing. Epigenetics Chromatin 2019, 12, 15. [CrossRef]

111. Yuan, H.; Li, N.; Fu, D.; Ren, J.; Hui, J.; Peng, J.; Liu, Y.; Qiu, T.; Jiang, M.; Pan, Q.; et al. Histone methyltransferase SETD2 modulates alternative splicing to inhibit intestinal tumorigenesis. J. Clin. Invest. 2017, 127, 3375-3391. [CrossRef]

112. Sureau, A.; Gattoni, R.; Dooghe, Y.; Stevenin, J.; Soret, J. SC35 autoregulates its expression by promoting splicing events that destabilize its mRNAs. EMBO J. 2001, 20, 1785-1796. [CrossRef]

113. Tilgner, H.; Nikolaou, C.; Althammer, S.; Sammeth, M.; Beato, M.; Valcarcel, J.; Guigo, R. Nucleosome positioning as a determinant of exon recognition. Nat. Struct. Mol. Biol. 2009, 16, 996-1001. [CrossRef]

114. Schwartz, S.; Meshorer, E.; Ast, G. Chromatin organization marks exon-intron structure. Nat. Struct. Mol. Biol. 2009, 16, 990-995. [CrossRef]

115. Shukla, S.; Kavak, E.; Gregory, M.; Imashimizu, M.; Shutinoski, B.; Kashlev, M.; Oberdoerffer, P.; Sandberg, R.; Oberdoerffer, S. CTCF-promoted RNA polymerase ii pausing links DNA methylation to splicing. Nature 2011, 479, 74-79. [CrossRef]

116. Iannone, C.; Pohl, A.; Papasaikas, P.; Soronellas, D.; Vicent, G.P.; Beato, M.; ValcaRcel, J. Relationship between nucleosome positioning and progesterone-induced alternative splicing in breast cancer cells. RNA 2015, 21, 360-374. [CrossRef]

117. Matveeva, E.; Maiorano, J.; Zhang, Q.; Eteleeb, A.M.; Convertini, P.; Chen, J.; Infantino, V.; Stamm, S.; Wang, J.; Rouchka, E.C.; et al. Involvement of PARP1 in the regulation of alternative splicing. Cell Discov. 2016, 2, 15046. [CrossRef]

118. Kim, Y.E.; Park, C.; Kim, K.E.; Kim, K.K. Histone and rna-binding protein interaction creates crosstalk network for regulation of alternative splicing. Biochem. Biophys. Res. Commun. 2018, 499, 30-36. [CrossRef]

119. Kfir, N.; Lev-Maor, G.; Glaich, O.; Alajem, A.; Datta, A.; Sze, S.K.; Meshorer, E.; Ast, G. SF3B1 association with chromatin determines splicing outcomes. Cell Rep. 2015, 11, 618-629. [CrossRef]

120. Maunakea, A.K.; Chepelev, I.; Cui, K.; Zhao, K. Intragenic DNA methylation modulates alternative splicing by recruiting MECP2 to promote exon recognition. Cell Res. 2013, 23, 1256-1269. [CrossRef]

121. Gu, H.; Bock, C.; Mikkelsen, T.S.; Jager, N.; Smith, Z.D.; Tomazou, E.; Gnirke, A.; Lander, E.S.; Meissner, A. Genome-scale DNA methylation mapping of clinical samples at single-nucleotide resolution. Nat. Methods 2010, 7, 133-136. [CrossRef]

122. Gelfman, S.; Cohen, N.; Yearim, A.; Ast, G. DNA-methylation effect on cotranscriptional splicing is dependent on GC architecture of the exon-intron structure. Genome Res. 2013, 23, 789-799. [CrossRef]

123. Yearim, A.; Gelfman, S.; Shayevitch, R.; Melcer, S.; Glaich, O.; Mallm, J.P.; Nissim-Rafinia, M.; Cohen, A.H.; Rippe, K.; Meshorer, E.; et al. HP1 is involved in regulating the global impact of DNA methylation on alternative splicing. Cell Rep. 2015, 10, 1122-1134. [CrossRef]

124. Fan, Y.; Li, H.; Liang, X.; Xiang, Z. Cbx3 promotes colon cancer cell proliferation by CDK6 kinase-independent function during cell cycle. Oncotarget 2017, 8, 19934-19946. [CrossRef]

125. Liu, M.; Huang, F.; Zhang, D.; Ju, J.; Wu, X.B.; Wang, Y.; Wu, Y.; Nie, M.; Li, Z.; Ma, C.; et al. Heterochromatin protein hp1gamma promotes colorectal cancer progression and is regulated by miR-30a. Cancer Res. 2015, 75, 4593-4604. [CrossRef]

126. Davie, J.R.; Xu, W.; Delcuve, G.P. Histone H3K4 trimethylation: Dynamic interplay with pre-mRNA splicing. Biochem. Cell Biol. 2016, 94, 1-11. [CrossRef]

127. Dhami, P.; Saffrey, P.; Bruce, A.W.; Dillon, S.C.; Chiang, K.; Bonhoure, N.; Koch, C.M.; Bye, J.; James, K.; Foad, N.S.; et al. Complex exon-intron marking by histone modifications is not determined solely by nucleosome distribution. PLoS ONE 2010, 5, e12339. [CrossRef] 
128. Keren-Shaul, H.; Lev-Maor, G.; Ast, G. Pre-mrna splicing is a determinant of nucleosome organization. PLoS ONE 2013, 8, e53506. [CrossRef]

129. Roda, D.; Castillo, J.; Telechea-Fernandez, M.; Gil, A.; Lopez-Rodas, G.; Franco, L.; Gonzalez-Rodriguez, P.; Rosello, S.; Perez-Fidalgo, J.A.; Garcia-Trevijano, E.R.; et al. EGF-induced acetylation of heterogeneous nuclear ribonucleoproteins is dependent on KRAS mutational status in colorectal cancer cells. PLoS ONE 2015, 10, e0130543. [CrossRef]

130. Riffo-Campos, A.L.; Castillo, J.; Vallet-Sanchez, A.; Ayala, G.; Cervantes, A.; Lopez-Rodas, G.; Franco, L. In silico RNA-seq and experimental analyses reveal the differential expression and splicing of EPDR1 and ZNF518B genes in relation to KRAS mutations in colorectal cancer cells. Oncol. Rep. 2016, 36, 3627-3634. [CrossRef]

131. Amirkhah, R.; Schmitz, U.; Linnebacher, M.; Wolkenhauer, O.; Farazmand, A. Microrna-mRNA interactions in colorectal cancer and their role in tumor progression. Genes Chromosomes Cancer 2015, 54, 129-141. [CrossRef]

132. Tao, Y.; Ma, C.; Fan, Q.; Wang, Y.; Han, T.; Sun, C. Microrna-1296 facilitates proliferation, migration and invasion of colorectal cancer cells by targeting SFPQ. J. Cancer 2018, 9, 2317-2326. [CrossRef]

133. Liang, Y.C.; Lin, W.C.; Lin, Y.J.; Lin, J.C. The impact of RNA binding motif protein 4-regulated splicing cascade on the progression and metabolism of colorectal cancer cells. Oncotarget 2015, 6, 38046-38060. [CrossRef]

134. Gonzalez, I.; Munita, R.; Agirre, E.; Dittmer, T.A.; Gysling, K.; Misteli, T.; Luco, R.F. A LncRNA regulates alternative splicing via establishment of a splicing-specific chromatin signature. Nat. Struct. Mol. Biol. 2015, 22, 370-376. [CrossRef]

135. Luco, R.F.; Pan, Q.; Tominaga, K.; Blencowe, B.J.; Pereira-Smith, O.M.; Misteli, T. Regulation of alternative splicing by histone modifications. Science 2010, 327, 996-1000. [CrossRef]

136. Taniguchi, K.; Sakai, M.; Sugito, N.; Kumazaki, M.; Shinohara, H.; Yamada, N.; Nakayama, T.; Ueda, H.; Nakagawa, Y.; Ito, Y.; et al. PTBP1-associated microRNA-1 and -133b suppress the warburg effect in colorectal tumors. Oncotarget 2016, 7, 18940-18952. [CrossRef]

137. Romero-Barrios, N.; Legascue, M.F.; Benhamed, M.; Ariel, F.; Crespi, M. Splicing regulation by long noncoding RNAs. Nucleic Acids Res. 2018, 46, 2169-2184. [CrossRef]

138. Zhu, L.Y.; Zhu, Y.R.; Dai, D.J.; Wang, X.; Jin, H.C. Epigenetic regulation of alternative splicing. Am. J. Cancer Res. 2018, 8, 2346-2358.

139. Song, X.; Zeng, Z.; Wei, H.; Wang, Z. Alternative splicing in cancers: From aberrant regulation to new therapeutics. Semin. Cell Dev. Biol. 2018, 75, 13-22. [CrossRef]

140. Tripathi, V.; Ellis, J.D.; Shen, Z.; Song, D.Y.; Pan, Q.; Watt, A.T.; Freier, S.M.; Bennett, C.F.; Sharma, A.; Bubulya, P.A.; et al. The nuclear-retained noncoding RNA MALAT1 regulates alternative splicing by modulating SR splicing factor phosphorylation. Mol. Cell 2010, 39, 925-938. [CrossRef]

141. Kong, J.; Sun, W.; Li, C.; Wan, L.; Wang, S.; Wu, Y.; Xu, E.; Zhang, H.; Lai, M. Long non-coding RNA LINC01133 inhibits epithelial-mesenchymal transition and metastasis in colorectal cancer by interacting with SRSF6. Cancer Lett. 2016, 380, 476-484. [CrossRef]

142. Wan, L.; Yu, W.; Shen, E.; Sun, W.; Liu, Y.; Kong, J.; Wu, Y.; Han, F.; Zhang, L.; Yu, T.; et al. SRSF6-regulated alternative splicing that promotes tumour progression offers a therapy target for colorectal cancer. Gut 2019, 68, 118-129. [CrossRef]

143. Ji, Q.; Zhang, L.; Liu, X.; Zhou, L.; Wang, W.; Han, Z.; Sui, H.; Tang, Y.; Wang, Y.; Liu, N.; et al. Long non-coding RNA MALAT1 promotes tumour growth and metastasis in colorectal cancer through binding to sfpq and releasing oncogene ptbp2 from sfpq/ptbp2 complex. Br. J. Cancer 2014, 111, 736-748. [CrossRef]

144. Yang, P.; Chen, T.; Xu, Z.; Zhu, H.; Wang, J.; He, Z. Long noncoding RNA GAPLINC promotes invasion in colorectal cancer by targeting SNAI2 through binding with PSF and NONO. Oncotarget 2016, 7, 42183-42194. [CrossRef]

145. Villamizar, O.; Chambers, C.B.; Riberdy, J.M.; Persons, D.A.; Wilber, A. Long noncoding RNA SAF and splicing factor 45 increase soluble FAS and resistance to apoptosis. Oncotarget 2016, 7, 13810-13826. [CrossRef]

146. Yin, J.; Luo, W.; Zeng, X.; Zeng, L.; Li, Z.; Deng, X.; Tan, X.; Hu, W. UXT-AS1-induced alternative splicing of UXT is associated with tumor progression in colorectal cancer. Am. J. Cancer Res. 2017, 7, 462-472.

147. Song, L.; Jia, J.; Peng, X.; Xiao, W.; Li, Y. The performance of the SEPT9 gene methylation assay and a comparison with other CRC screening tests: A meta-analysis. Sci. Rep. 2017, 7, 3032. [CrossRef] 
148. Liao, H.K.; Hatanaka, F.; Araoka, T.; Reddy, P.; Wu, M.Z.; Sui, Y.; Yamauchi, T.; Sakurai, M.; O’Keefe, D.D.; Nunez-Delicado, E.; et al. In vivo target gene activation via CRISPR/cas9-mediated trans-epigenetic modulation. Cell 2017, 171, 1495-1507.e15. [CrossRef]

149. Stypula-Cyrus, Y.; Damania, D.; Kunte, D.P.; Cruz, M.D.; Subramanian, H.; Roy, H.K.; Backman, V. Hdac up-regulation in early colon field carcinogenesis is involved in cell tumorigenicity through regulation of chromatin structure. PLoS ONE 2013, 8, e64600. [CrossRef]

150. Deng, X.; Ruan, H.; Zhang, X.; Xu, X.; Zhu, Y.; Peng, H.; Zhang, X.; Kong, F.; Guan, M. Long non-coding RNA CCAL transferred from fibroblasts by exosomes promotes chemoresistance of colorectal cancer cells. Int. J. Cancer 2019. [CrossRef]

151. Chen, H.; Xu, J.; Hong, J.; Tang, R.; Zhang, X.; Fang, J.Y. Long noncoding rna profiles identify five distinct molecular subtypes of colorectal cancer with clinical relevance. Mol. Oncol. 2014, 8, 1393-1403. [CrossRef]

152. James de Bony, E.; Bizet, M.; Van Grembergen, O.; Hassabi, B.; Calonne, E.; Putmans, P.; Bontempi, G.; Fuks, F. Comprehensive identification of long noncoding rnas in colorectal cancer. Oncotarget 2018, 9, 27605-27629.

153. Surguchov, A.; Surgucheva, I.; Sharma, M.; Sharma, R.; Singh, V. Pore-forming proteins as mediators of novel epigenetic mechanism of epilepsy. Front. Neurol. 2017, 8, 3. [CrossRef]

154. Srinivas Patnaik, A. Drugs targeting epigenetic modifications and plausible therapeutic strategies against colorectal cancer. Front. Pharmacol. 2019, 10, 588. [CrossRef]

155. Matsui, M.; Corey, D.R. Non-coding RNAs as drug targets. Nat. Rev. Drug Discov. 2017, 16, $167-179$. [CrossRef]

156. Jothimani, G.; Sriramulu, S.; Chabria, Y.; Sun, X.F.; Banerjee, A.; Pathak, S. A review on theragnostic applications of micrornas and long non-coding rnas in colorectal cancer. Curr. Top. Med. Chem. 2018, 18, 2614-2629. [CrossRef]

157. Beg, M.S.; Brenner, A.J.; Sachdev, J.; Borad, M.; Kang, Y.K.; Stoudemire, J.; Smith, S.; Bader, A.G.; Kim, S.; Hong, D.S. Phase I study of MRX34, a liposomal miR-34a mimic, administered twice weekly in patients with advanced solid tumors. Investig. New Drugs 2017, 35, 180-188. [CrossRef]

158. Wang, F.; Ma, Y.; Wang, H.; Qin, H. Reciprocal regulation between micrornas and epigenetic machinery in colorectal cancer. Oncol. Lett. 2017, 13, 1048-1057. [CrossRef]

159. Xiang, S.; Zou, P.; Tang, Q.; Zheng, F.; Wu, J.; Chen, Z.; Hann, S.S. Hotair-mediated reciprocal regulation of EZH2 and DNMT1 contribute to polyphyllin I-inhibited growth of castration-resistant prostate cancer cells in vitro and in vivo. Biochim. Biophys. Acta. Gen. Subj. 2018, 1862, 589-599. [CrossRef]

160. Li, Y.; Ren, Y.; Wang, Y.; Tan, Y.; Wang, Q.; Cai, J.; Zhou, J.; Yang, C.; Zhao, K.; Yi, K.; et al. A compound AC1Q3QWB selectively disrupts HOTAIR-mediated recruitment of PRC2 and enhances cancer therapy of DZNep. Theranostics 2019, 9, 4608-4623. [CrossRef]

161. Sarma, K.; Levasseur, P.; Aristarkhov, A.; Lee, J.T. Locked nucleic acids (LNAS) reveal sequence requirements and kinetics of XIST RNA localization to the x chromosome. PNAS 2010, 107, 22196-22201. [CrossRef]

162. Amodio, N.; Stamato, M.A.; Juli, G.; Morelli, E.; Fulciniti, M.; Manzoni, M.; Taiana, E.; Agnelli, L.; Cantafio, M.E.G.; Romeo, E.; et al. Drugging the lncRNA MALAT1 via lna gapmeR ASO inhibits gene expression of proteasome subunits and triggers anti-multiple myeloma activity. Leukemia 2018, 32, 1948-1957. [CrossRef]

163. Naderi-Meshkin, H.; Lai, X.; Amirkhah, R.; Vera, J.; Rasko, J.E.J.; Schmitz, U. Exosomal lncrnas and cancer: Connecting the missing links. Bioinformatics 2019, 35, 352-360. [CrossRef]

164. Wu, Y.; Yang, X.; Chen, Z.; Tian, L.; Jiang, G.; Chen, F.; Li, J.; An, P.; Lu, L.; Luo, N.; et al. M(6)a-induced lncRNA RP11 triggers the dissemination of colorectal cancer cells via upregulation of ZEB1. Mol. Cancer 2019, 18, 87. [CrossRef]

165. Sun, T.; Wu, R.; Ming, L. The role of m6a RNA methylation in cancer. Biomed. Pharmacother. 2019, 112, 108613. [CrossRef]

166. Pan, Y.; Ma, P.; Liu, Y.; Li, W.; Shu, Y. Multiple functions of m(6)a RNA methylation in cancer. J. Hematol. Oncol. 2018, 11, 48. [CrossRef]

167. Jacob, R.; Zander, S.; Gutschner, T. The dark side of the epitranscriptome: Chemical modifications in long non-coding RNAs. Int. J. Mol. Sci. 2017, 18, 2387. [CrossRef]

168. Cohen, A.J.; Saiakhova, A.; Corradin, O.; Luppino, J.M.; Lovrenert, K.; Bartels, C.F.; Morrow, J.J.; Mack, S.C.; Dhillon, G.; Beard, L.; et al. Hotspots of aberrant enhancer activity punctuate the colorectal cancer epigenome. Nat. Commun. 2017, 8, 14400. [CrossRef] 
169. Gilbert, L.A.; Horlbeck, M.A.; Adamson, B.; Villalta, J.E.; Chen, Y.; Whitehead, E.H.; Guimaraes, C.; Panning, B.; Ploegh, H.L.; Bassik, M.C.; et al. Genome-scale crispr-mediated control of gene repression and activation. Cell 2014, 159, 647-661. [CrossRef]

170. Blanas, A.; Cornelissen, L.A.M.; Kotsias, M.; van der Horst, J.C.; van de Vrugt, H.J.; Kalay, H.; Spencer, D.I.R.; Kozak, R.P.; van Vliet, S.J. Transcriptional activation of fucosyltransferase (FUT) genes using the CRISPR-dCas9-VPR technology reveals potent $N$-glycome alterations in colorectal cancer cells. Glycobiology 2019, 29, 137-150. [CrossRef]

171. Bester, A.C.; Lee, J.D.; Chavez, A.; Lee, Y.R.; Nachmani, D.; Vora, S.; Victor, J.; Sauvageau, M.; Monteleone, E.; Rinn, J.L.; et al. An integrated genome-wide CRISPRA approach to functionalize lncRNAs in drug resistance. Cell 2018, 173, 649-664.e20. [CrossRef]

172. Thakore, P.I.; D'Ippolito, A.M.; Song, L.; Safi, A.; Shivakumar, N.K.; Kabadi, A.M.; Reddy, T.E.; Crawford, G.E.; Gersbach, C.A. Highly specific epigenome editing by CRISPR-CAS9 repressors for silencing of distal regulatory elements. Nat. Methods 2015, 12, 1143-1149. [CrossRef]

173. Zhang, X.; Choi, P.S.; Francis, J.M.; Gao, G.F.; Campbell, J.D.; Ramachandran, A.; Mitsuishi, Y.; Ha, G.; Shih, J.; Vazquez, F.; et al. Somatic superenhancer duplications and hotspot mutations lead to oncogenic activation of the KLF5 transcription factor. Cancer Discov. 2018, 8, 108-125. [CrossRef]

174. Choudhury, S.R.; Cui, Y.; Lubecka, K.; Stefanska, B.; Irudayaraj, J. CRISPR-dCas9 mediated TET1 targeting for selective DNA demethylation at BRCA1 promoter. Oncotarget 2016, 7, 46545-46556. [CrossRef]

175. Vojta, A.; Dobrinic, P.; Tadic, V.; Bockor, L.; Korac, P.; Julg, B.; Klasic, M.; Zoldos, V. Repurposing the crispr-cas9 system for targeted DNA methylation. Nucleic Acids Res. 2016, 44, 5615-5628. [CrossRef]

176. Shechner, D.M.; Hacisuleyman, E.; Younger, S.T.; Rinn, J.L. Multiplexable, locus-specific targeting of long RNAs with CRISPR-display. Nat. Methods 2015, 12, 664-670. [CrossRef]

177. Amirkhah, R.; Farazmand, A.; Wolkenhauer, O.; Schmitz, U. RNA systems biology for cancer: From diagnosis to therapy. Methods Mol. Biol. 2016, 1386, 305-330.

178. Van Leeuwen, I.M.M.; Edwards, C.M.; Ilyas, M.; Byrne, H.M. Towards a multiscale model of colorectal cancer. World J. Gastroenterol. 2007, 13, 1399-1407. [CrossRef]

179. De Matteis, G.; Graudenzi, A.; Antoniotti, M. A review of spatial computational models for multi-cellular systems, with regard to intestinal crypts and colorectal cancer development. J. Math. Biol. 2013, 66, 1409-1462. [CrossRef]

180. Kirouac, D.C.; Schaefer, G.; Chan, J.; Merchant, M.; Orr, C.; Huang, S.-M.A.; Moffat, J.; Liu, L.; Gadkar, K.; Ramanujan, S. Clinical responses to ERK inhibition in BRAFV600e-mutant colorectal cancer predicted using a computational model. NPJ Syst. Biol. Appl. 2017, 3, 14. [CrossRef]

181. Vafaee, F.; Diakos, C.; Kirschner, M.B.; Reid, G.; Michael, M.Z.; Horvath, L.G.; Alinejad-Rokny, H.; Cheng, Z.J.; Kuncic, Z.; Clarke, S. A data-driven, knowledge-based approach to biomarker discovery: Application to circulating microrna markers of colorectal cancer prognosis. NPJ Syst. Biol. Appl. 2018, 4, 20. [CrossRef] 